\title{
ecgi
}

\section{Industrial Foundations as Long-Term Owners}

Finance Working Paper $N^{\circ}$ 556/2018

March 2018

\section{Steen Thomsen}

Copenhagen Busniess School and ECGI

Thomas Poulsen

Copenhagen Busniess School

Christa Børsting

Copenhagen Business School

Johan Kuhn

Copenhagen Business School

(C) Steen Thomsen, Thomas Poulsen, Christa Børsting and Johan Kuhn 2018. All rights reserved. Short sections of text, not to exceed two paragraphs, may be quoted without explicit permission provided that full credit, including (C) notice, is given to the source.

This paper can be downloaded without charge from: http://ssrn.com/abstract_id=2725462

www.ecgi.org/wp 


\title{
Industrial Foundations as Long-Term Owners
}

\author{
Working Paper N 556/2018 \\ March 2018 \\ Steen Thomsen \\ Thomas Poulsen \\ Christa Børsting \\ Johan Kuhn
}

(C) Steen Thomsen, Thomas Poulsen, Christa Børsting and Johan Kuhn 2018. All rights reserved. Short sections of text, not to exceed two paragraphs, may be quoted without explicit permission provided that full credit, including (C) notice, is given to the source. 


\begin{abstract}
Short-termism has become a serious concern for corporate governance, and this has inspired a search for institutional arrangements to promote long-term decision-making. In this paper, we call attention to long-term ownership by industrial foundations, which is common in Northern Europe but little known in the rest of the world. We use a unique Danish data set to document that industrial foundations are long-term owners that practice long-term governance. We show that foundation ownership is highly stable compared to other ownership structures. Foundation-owned companies replace managers less frequently. They have conservative capital structures with low financial leverage. They score higher on an index of long-termism in finance, investment, and employment. They survive longer. Overall, our paper supports the hypothesis that corporate time horizons are influenced by ownership structures and particularly that industrial foundations possess characteristics that promote long-termism. Policymakers, business owners, and managers interested in promoting long-term governance models should therefore reconsider the role of ownership structure.
\end{abstract}

Keywords: Corporate governance, industrial foundations, long-termism

JEL Classifications: G34

\author{
Steen Thomsen \\ Professor \\ Copenhagen Business School, Department of International \\ Economics and Management \\ Porcelaenshaven 24a \\ 2000 F Copenhagen, Denmark \\ phone: +4538152590 \\ e-mail: st.int@cbs.dk \\ Thomas Poulsen* \\ Associate Professor \\ Copenhagen Business School, Department of International \\ Economics and Management \\ Porcelaenshaven 24 \\ 2000 Frederiksberg, Denmark \\ phone: +4538153458 \\ e-mail: Tpo.int@cbs.dk \\ Christa Børsting \\ Researcher \\ Copenhagen Business School, Department of International \\ Economics and Management \\ Porcelaenshaven 24 \\ 2000 Frederiksberg, Denmark \\ phone: +45381526 30 \\ e-mail:cdb.int@cbs.dk \\ Johan Kuhn \\ Researcher \\ Copenhagen Business School \\ Porcelaenshaven 24A \\ 2000 Frederiksberg, Denmark \\ phone: +45 51512609 \\ e-mail: johan@epacn.dk
}




\title{
INDUSTRIAL FOUNDATIONS AS LONG-TERM OWNERS
}

\author{
Steen Thomsen, Thomas Poulsen, ${ }^{1}$ Christa Børsting, and Johan Kuhn \\ Copenhagen Business School \\ Department of International Economics and Management \\ Center for Corporate Governance
}

\begin{abstract}
Short-termism has become a serious concern for corporate governance, and this has inspired a search for institutional arrangements to promote long-term decision-making. In this paper, we call attention to long-term ownership by industrial foundations, which is common in Northern Europe but little known in the rest of the world. We use a unique Danish data set to document that industrial foundations are long-term owners that practice long-term governance. We show that foundation ownership is highly stable compared to other ownership structures. Foundation-owned companies replace managers less frequently. They have conservative capital structures with low financial leverage. They score higher on an index of long-termism in finance, investment, and employment. They survive longer. Overall, our paper supports the hypothesis that corporate time horizons are influenced by ownership structures and particularly that industrial foundations possess characteristics that promote long-termism. Policymakers, business owners, and managers interested in promoting long-term governance models should therefore reconsider the role of ownership structure.
\end{abstract}

Keywords: Corporate governance, industrial foundations, long-termism.

\footnotetext{
${ }^{1}$ Corresponding author. Email: Tpo.int@cbs.dk. Phone: +45 38153458. Address: Porcelaenshaven 24, 2000 Frederiksberg, Denmark.
} 


\section{INTRODUCTION}

Concerns about short-termism have been mounting in recent years (Phelps, 2010; Bair, 2011; Roe, 2013; Mayer, 2013; McKinsey, 2015) and have influenced the proposed EU shareholder directive (European Council, 2016), the US presidential debate (Reuters, 2015), and the French Florange Act (Solomon, 2015). Larry Fink, CEO of Blackrock, the largest investor in the world, is worried (Fink, 2016). Scholars, politicians, and executives argue that companies pursue short-run profitability (McKinsey, 2015) at the expense of long-run investments (Sampson and Shi, 2016) and sustainability (Stiglitz, 2016). The perceived trends are blamed on corporate governance related issues like incentive pay (Bolton, Scheinkman, and Xiong, 2006; Bhagat and Bolton, 2014; Ladika and Sautner, 2014), quarterly reports (Kim, Su, and Zhu, 2016), share analysts (Desjardine, 2015), takeover threats (Stein, 1988, 1989; Asker et al., 2011, 2015; Wang, Zhao, and He, 2015), managerial turnover (Kaplan and Minton, 2012), or speculative stock market fluctuations (Cremers, Pareek, and Sautner, 2013). Several remedies have been suggested including loyalty shares (extra voting rights or dividends for long-term shareholders; Johnson, 2015; Solomon 2015), abolishing quarterly reports and earnings guidance (Kay, 2012), bonus caps (the EU Capital Requirements Directive), or limiting hostile takeovers (Milliband, 2012).

In this paper, we focus on the pivotal role of long-term ownership as a remedy to short-termism. Previous research has pointed to long time horizons in family businesses (Chua, Chrisman, and Bergiel, 2009; Asker et al., 2011, 2015; Kachaner, Stalk, and Bloch, 2012; Kappes and Schmid, 2013) and short time horizons in companies owned by transient financial investors (Bushee, 1998; Croce, Stewart, and Yermo, 2011; Thanassoulis and Somekh, 2016; Zhang and Gimeno, 2016). Following Mayer (2013), we argue that committed long-term shareholders have the power and the incentives to take into account the long-run effects of their behaviour, including their choice of governance structures, because 
they are more likely to be around to face the consequences of their decisions. Thus, if we can fix ownership structure, we may be able to fix some of the problems of short-termism.

Building on previous work by Schelling (1960, 1985), Kreps (1990), and Mayer (2013), we propose that a credible long-term ownership commitment enables companies to avoid the performance loss due to short-termism and to engage in mutually beneficial implicit contracts with stakeholders (see also Uhlaner, Floren, and Geerling, 2007; Cremers, Masconale, and Sepe, 2016). Companies and their stakeholders may benefit from a commitment not to breach such implicit contracts, even when doing so would maximize profits ex post. For example, employees are more likely to be loyal if they trust that they will be rewarded by stable employment, even if the company could increase its immediate profitability by laying-off employees (Kreps, 1990).

We test these ideas on corporate ownership by "industrial foundations", which are independent non-profit institutions, whose most important goal is the preservation of a business company (Thomsen, 2017). Our research question is whether foundation ownership leads to long-term corporate governance of foundation-owned companies. We argue that industrial foundations are, by design, long-term owners, even compared to family ownership, because their charters oblige them to long-run ownership and company survival. Thus, they provide an ideal setting in which to study the impact of long-term ownership.

We use a unique Danish data set to test whether foundation ownership is associated with long-term governance indicators like ownership and management stability, capital structure, and investments, employment, and corporate survival. Foundation ownership is observed around the world in companies like Bosch (Germany), Bertelsmann (Germany), Hershey (US), Tata (India), or Rolex (Switzerland), but it is most common in 
Northern Europe and particularly in Denmark, which makes it feasible to do statistical studies on Danish data.

The paper fills a gap in the sparse research literature on industrial foundations, which has hitherto focused mainly on the consequences of foundation ownership for financial performance (Thomsen, 1996, 1999; Hermann and Franke, 2002; Thomsen and Rose, 2004; Dzansi, 2012). At the same time, we contribute to the growing literature on long-termism and short-termism in corporate governance. Using data on a uniquely long-term ownership type, we provide new evidence of the impact of ownership on corporate time horizons. Our study is important because a growing body of academic research has shown that increasingly short time horizons among corporations and investors have led companies to focus excessively on current earnings and underinvest in the future to the detriment of shareholders and society at large (Sampson and Shi, 2016; Souder, Reilly, Bromiley, and Mitchell, 2016; Reilly, Souder, and Ranucci, 2016). It is therefore important to find remedies for short-termism.

We show that industrial foundations are, in fact, highly stable owners compared to other owner types. Moreover, as expected, foundation-owned companies are characterized by long-term governance, including stable management, low financial leverage, long-run investments, and higher survival rates. Overall, we find that foundation-owned companies are more long-term than firms with other ownership structures.

Our paper contributes to current corporate governance research by identifying the important role of ownership commitment in promoting long-term corporate governance. In doing this, we also find support for the part of the literature that points to the limited generalization of agency theory because of its strong dependence on corporate governance context (see e.g. Kappes and Schmid, 2013; Choi, Park, \& Hong, 2012). Secondarily, we 
contribute to the limited literature on industrial foundations, which we show to be a vehicle for long-termism in corporate governance.

\section{THEORETICAL DISCUSSION AND HYPOTHESIS DEVELOPMENT}

Long-termism and short-termism can be conceived as extremes on a continuous scale, temporal orientation, which measures "the relative cognitive dominance of the near versus distant future" (Das, 1987: 203; Reilly et al., 2016). The concept was originally developed to measure variation in the future orientation of individuals and subsequently applied to the firm level (Marginson and McAulay, 2008; Souder and Bromiley, 2012; Reilly et al., 2016). Temporal orientation influences the (subjective) weight that corporate decision-makers attach to present and future time periods. In allocating effort, capital, or other resources over time, the discount factor, $1 /(1+\mathrm{d})^{\mathrm{t}}$, measures the relative weight attached to future outcomes (at time t). Intuitively, the higher the discount rate, $d$, the less weight or importance corporate decision makers attach to future outcomes and the shorter their time horizons. "Firms that routinely select short horizon projects can be described as having a short investment horizon and vice versa for firms that routinely select longer horizon project alternatives" (Reilly et al., 2016: 1173).

Short-termism can be defined by high subjective discount rates that lead managers to forego good long-term opportunities (Marginson and McAulay, 2008; Reilly et al., 2016), i.e. discount rates that exceed the costs of capital and therefore, when applied to corporate decision-making, lead to sub-optimal value creation from the viewpoint of outside investors (Sauder et al., 2016). Empirical evidence indicates that US managers, on average, use discount rates of around double the weighted average costs of capital (Poterba and Summers, 1995; Jagannathan, Matsa, Meier, and Tarhan, 2014), which implies that their 
companies would be financially better off with longer time horizons (Souder et al., 2016). In contrast, long-termism may be defined as decision-making by means of discount rates that are closer to the market-determined cost of capital. In principle, discount rates could be set below the costs of capital, which would lead to overinvestment and sub-optimal value creation (Levinthal and March, 1993), but such excessive long-termism can be regarded as a selfcontradiction, since it compromises the long-term financial viability of a company.

We identify two theoretically distinct distortions that interact to produce inefficient short-termism.

First, short-termism may arise as a consequence of information asymmetries between rational and self-interested agents. This is the case in the models developed by Stein (1988, 1989), where fear of a takeover induces managers to cut down on unobservable investments in order to increase short-term profits. The same applies to the "limits to arbitrage" model of Shleifer and Vishny (1990), who argue that higher costs of arbitrage in long-term goods lead managers to underinvest in them. An excessive focus on short-term results may also be caused by career motives (Thakor, 1990), short-term bonus systems (Hill et al., 1992), stock options compensation (Souder and Shaver, 2010; Ladika and Sautner, 2014), residual pay (Thanassoulis, 2013), debt pressure (Desyllas and Hughes, 2010), or high management turnover (Palley, 1997; Kaplan and Minton, 2012).

Second, behavioural biases may lead individuals or organizations to focus irrationally on short-term outcomes (Thaler, 1981; Thaler, Tversky, Kahneman, and Schwartz, 1997; Souder et al., 2016). For example, Thaler (1981) observed implied discount rates of 25 percent and up to 100 percent in experimental settings. This is consistent with behavioural theories of the firm in which companies react to their immediate problems rather than engage in rational, long-term planning (Cyert and March, 1963; Bromily, 2016). While 
behavioural biases may reflect cognitive limitations (Levinthal and March, 1993), impatience (Reuben, Sapienza, and Zingales, 2015), or other traits of human nature (Frederick, Loewenstein, and O'Donoghue, 2002), they can at least to some extent be managed by selfcontrol and other mechanisms (Schelling, 1985). The psychologist Walter Mischel famously asked children to delay eating a marshmallow, for which they were promised two future marshmallows as a reward for delayed gratification (Mischel and Ebbesen, 1970; Mischel, Shoda, and Rodriguez, 1989; Mischel and Ayduk, 2004; Mischel, 2014). Some children were unable to withstand the temptation, but others developed coping strategies that allowed them to prevail. Mischel discovered that a high level of trust was crucial for their patience, which connects to the theory of social capital and trust in organizations (Scheling, 1985; Mayer and Schoorman, 1995; LaPorta et al., 1997; Mayer, 2013; Mischel, 2014).

In this paper, we propose that long-term ownership may act as a commitment mechanism in the sense of Schelling (1960). Similar notions of ownership commitment have been applied to family business (Uhlaner, Floren, and Geerlings, 2007), and to voluntary limitations on shareholder rights (Cremers, Masconale, and Sepe, 2016). With Schelling (1960, 1985), Kreps (1990), and Mayer (2013) we argue that companies may benefit from a credible commitment not to breach such implicit contracts with stakeholders. For example, employees are presumably more likely to be loyal if they trust that they will be rewarded by continuing future employment (Kreps, 1990). We propose that long-term owners can make such commitments more credibly, since they are more likely to have to face the future consequences of breaching them. Moreover, we argue below that this long-term commitment is particularly credible in the case of foundation ownership, where the personal profit motive is eliminated (Hansmann, 1980). 


\section{Ownership and long-termism}

With Roe (2013), we argue that short-term ownership is a key driver of general short-termism. Institutional or behavioural biases may focus the attention of decision-makers on one part of the time axis (the present) while the rest (the future) is not taken into account (Slawinski and Bansal, 2012; Bansal and DesJardine, 2014). Long-term owners, who hold on to their shares, cut across the divided time line; and as such they have incentives to make decisions and set up governance structures that promote long-term decision making, including stable management, sustainable debt levels, strategic persistence, or investments in R\&D. We therefore focus on ownership stability as a key determinant of long-termism.

Empirical research has found that volatile ownership by financial investors is associated with greater short-termism. For example, Bushee (1998) found that short-term institutional investment was associated with lower R\&D expenditure. Zhang and Gimeno (2016) find that short-term earnings pressures harm competitiveness, but that long-term shareholders are better able to maintain competitive strategies. Thanassoulis and Somekh (2016) find that Germanic firms with more stable shareholders have lower cost of equity (i.e. lower discount rates and thus a longer time horizon) than comparable US companies who have more short-term shareholders.

Family-owned businesses are generally assumed to have longer time horizons than investor-owned companies (Chua, Chrisman, and Bergiel, 2009; Reilly et al., 2016), and in this respect they are sometimes regarded as role models for other companies (Kachaner, Stalk, and Bloch, 2012). Their long time horizons may follow from the concerns for the welfare of future generations that motivates the present-generation owners to invest in the long term (James, 1999; Zellweger, 2007). Empirically, Asker et al. (2011, 2015) find that private firms outperform public firms financially, and they attribute the difference to greater 
long-termism. Family businesses are also better able to avoid income-smoothing (Prencipe, Bar-Yosef, Mazzola, and Pozza, 2011), and their financing, investment, and employment policies tend to be more long-term (Kappes and Schmid, 2013). ${ }^{1}$

\section{Foundation ownership and long-termism}

Positioning industrial foundations in the "ownership and long-termism" literature, it seems clear that foundation ownership have more features in common with family business than with investor ownership. Like family business, foundation ownership involves concentrated ownership, and members of the founding family remain active on the boards of many industrial foundations. However, some of the defining characteristics of foundation ownership arguably make it even more long-term than family ownership.

First, a long-term ownership commitment is typically formalized in the foundation charter, which makes ownership of the company the most important objective for the foundations in question (Thomsen and Degn, 2014). Secondly, foundation ownership is not subject to the travails of succession to new generations of the founding family. Ownership remains with the foundation; it is not an option for new generations to cash in by selling their shares. Thirdly, foundations are patient owners, since they have no residual claimants who can demand dividends (Hansmann, 1980). The personal profit motive and the incentive to maximize short-run profits is consequently absent or at least muted.

Several other factors appear to reinforce long-termism in foundation-owned companies. For example, a conservative long-term orientation is arguably inherent in the legal structure of industrial foundations, which, as perpetuities, have an obligation to preserve their endowment. Unlike companies, foundations cannot (except in bankruptcy) be dissolved 
as long as their purpose is still valid. Finally, like family businesses, foundation-owned companies are relatively immune to short-termism biases imposed by takeover threats (Stein, 1988, 1989).

From a family business point of view, an industrial foundation is a commitment mechanism, by which the founding family commits to maintain its ownership indefinitely. Alternative, less binding commitment mechanisms could be shareholder agreements, dual class stocks, family holding companies, family councils, and succession planning (Caspar, Dias, and Elstrodt, 2010). Shareholder agreements can prevent ownership dilution by regulating voting and divestment of shares (Milston and Cohn 1967; Goergen, Renneboog, and Khurshed, 2006; Chemla, Habib, and Ljungqvist, 2007). Dual class stocks - recently popular with US tech companies like Google, Facebook and LinkedIn - make it easier for the family to retain control (Villalonga and Amit, 2009; Howell, 2017). Family governance through holding companies, coordination of family interests in family councils, and succession planning of executive and non-executive directorships can serve the same function (White, Krinke, and Geller, 2004; Gilding, 2005; Kotlar and De Massis, 2013; Gnan, Montemerlo, and Huse, 2015; Zellweger and Kammerlander, 2015). But foundation ownership is distinguished from these mechanisms by being more radical, since it involves an irrevocable transfer of ownership and wealth to the foundation. It is also worth noting that foundation ownership is not just used in family businesses but functions as an alternative arrangement when it is difficult or impractical for the founding family to retain its governance role, for example when there are no descendants or no descendants who are qualified or willing to take over.

All told, foundation-owned companies have many features in common with family businesses, but foundation ownership is distinguished by an additional and irrevocable commitment to the continuation of the company. We therefore propose that foundation- 
owned companies will have longer time horizons than family firms, which have been found to have longer time horizons than investor-owned firms.

To be sure, many founding families have an equally strong commitment to the continuation of the family business, but there are also examples of conflicts among descendants (Levinson, 1971; Gordon and Nicholson, 2008) whose loyalty to the firm is weakened over time in ways that may lead to myopic behaviour (Bianco, Bontempi, Golinelli, and Parigi, 2013). In fact, avoiding such scenarios may have been a motive for some founders to establish industrial foundations in the first place. In sum, we propose:

Hypothesis 1. Foundation ownership will be more stable than ownership by other controlling shareholders.

We regard long-term ownership commitment as pivotal in endowing the company with a long-run perspective on corporate governance. This includes top management continuity, capital structure, and long-term investments with the ultimate goal of corporate survival. Although we examine these variables individually below, it is important to stress that we regard them as part of a whole, i.e. a bundle of governance characteristics (García-Castro, Aguilera, and Ariño, 2013) with complementary characteristics (Holstrøm and Milgrom, 1994), cf. Figure 1. We conjecture that the foundation governance bundle will be informed by the long-term commitment of key decision-makers, starting with the entrepreneur or founder who established the foundation to preserve the company. Complementarity implies that there will be some level of consistency between the different parts of the bundle. For example, as we argue below, foundation-ownership will be associated with both low leverage and high survival rates, but it is also the case that low leverage has a positive effect on the probability of survival. Likewise, low financial leverage will put less 
pressure on managers and thereby increase management continuity. Both low leverage and management continuity will, in turn, be associated with more long-term investments.

[Please insert Figure 1 here]

Given the stability of foundation ownership (H1), we hypothesize that we will observe lower managerial turnover in foundation-owned companies. As patient long-term owners, industrial foundations are expected to be less concerned with short-term financial results and more with long-term development of the company. Because of their long time horizons, they also have an interest in avoiding the short-termism and inefficiency of rapid management changes (Palley, 1997; Kaplan and Minton, 2012). This is consistent with previous research, which finds that changes in ownership and board structure tend to be correlated (Denis and Sarin, 1999). For example, management is often replaced after M\&A (Martin and McConnell, 1991) and leveraged buyouts (Gong and Wu, 2011). We therefore propose:

Hypothesis 2. Foundation-owned companies will have greater continuity of management (fewer exits) than other companies.

We also hypothesize that foundation-owned firms will be less leveraged and have higher equity share ratios. This stems, at least partly, from their long-term ownership commitment and their preference for company survival. Radner (1998), Dutta and Radner (1999), and Dutta and Sundaram (2001) show theoretically that survival maximizing companies tend to have more conservative capital structures, which makes them more resilient to demand shocks, and therefore more likely to survive. Oprea (2014) recently found support for these insights in an experimental setting. We therefore regard low leverage (high equity share) as an indicator of long-termism. It is well understood that firms can raise shortterm profitability by leveraging up but that this increases financial risk; the financial crisis of 
2008-9 was widely blamed on this kind of short-termism. Desyllas and Hughes (2010) find that increasing financial leverage reduces R\&D spending. Opler \& Titman (1994) find that financially distressed firms with high leverage lose market shares. Related research on family business finds that family firms have lower financial leverage and greater risk aversion (Ampenberger, Schmid, and Achleitner, 2013; Hiebl 2013; Belenzon, Patacconi, and Zarutskie, 2016). We therefore propose that:

Hypothesis 3. Foundation-owned firms have less financial leverage and higher equity ratios than other firms.

Because of their patient long-term ownership, we propose that foundationowned companies are less likely to be concerned with short-term profits and more likely to make long-term investments. They are also more likely to be stable, long-term employers (Børsting and Thomsen, 2016). We follow Kappes and Schmid (2013) in combining a set of accounting variables as indicators of long-termism, including $R \& D$ expenditure, capital expenditure, asset maturity, sales growth, sales per employee, debt maturity, and liquidity. Our hypothesis is that foundation-owned firms have more stable business behaviour and therefore have higher realizations of these indicators.

While the case for foundation ownership and long-termism appears compelling, we note that, as with family firms, there are potential counter arguments, which could make foundation-owned firms less long-term oriented. For example, their reliance on selffinancing, and their unwillingness to dilute ownership, could constrain their access to capital. Thus, the time preferences of foundation-owned companies are contingent of the availability of internal funds. Patient ownership will typically allow foundation-owned companies to retain earnings for promising investments. However, beyond the capital invested by the foundation, the costs of outside capital may be high. We propose: 
Hypothesis 4. Foundation-owned firms will display more long-term oriented business behaviour than other firms.

We regard company survival as the ultimate measure of successful longtermism (Collins and Porras, 1997; de Geus, 1997). While there are no previous studies of foundation-owned companies' survival, related research tends to find higher survival rates for family businesses (Wilson et al., 2013; Belenzon, Patacconi, and Zarutskie, 2016). We expect foundation-owned companies to survive longer than investor-owned companies for several reasons. First, preservation of the company is an objective (explicitly or implicitly) in most industrial foundations. Secondly, foundations are perpetuities with an obligation to preserve their capital of which the ownership in the underlying company is a major part (Thomsen, 2017). Third, an attenuated profit motive implies less strong incentives to sell out (Hansmann, 1980). Fourth, financial conservatism and stability should generally make foundation-owned firms more resilient to external shocks (Dutta and Radner, 1999). Fifth, foundation-owned companies will not to the same extent as family-owned companies be subject to the disruptions of ownership succession. In sum, we therefore propose that:

Hypothesis 5. Foundation-owned firms will survive longer than other firms.

\section{SAMPLE SELECTION AND VARIABLE DESCRIPTION}

\section{Sample selection}

The many dimensions of long-termism that we consider in this paper require a composite sample selection. Our starting point is the Danish Business Authority's register on industrial foundations. We delete foundations without business activity outside the foundation, and foundations with charitable and government-linked activities for which 
business concerns are secondary. We use ownership data from an accounting database (Experian) to identify the business firms controlled by foundations. ${ }^{2}$ There are about 1,600 such firms in any given year. We take stock in year 2003 and these firms are the primary subjects of analysis in this paper. Firm characteristics together with income statement data and balance sheet data are obtained from Experian. Once we exclude all financial firms, and add a firm size criterion of minimum 1 million DKK in total assets (around 130,000 EUR), we end up with 394 firms owned by industrial foundations. We have data for each year from 2003 to 2012 .

We compare these foundation-owned firms to other limited liability firms subject to the same minimum size criterion. There are about 50,000 firms of this kind in our data in any given year. However, foundation-owned firms are much larger on average, for example they have more employees (817) than firms in general (38). To avoid confounding size and ownership effects, we provide separate analyses for large firms with 100 million DKK or more in total assets.

We also compare foundation-owned firms with the somewhat similar familyowned firms. We adopt the most inclusive definition and categorize non-foundation owned firms as family-owned if a family has at least 5 percent ownership (Villalonga and Amit, 2006; Anderson and Reeb, 2003). This low threshold is chosen because families have been found to control firms even with very moderate equity stakes. By this definition, about 40 percent of the non-foundation-owned firms are family firms.

\section{Variable description}

Dependent variables. As outlined in the development of our hypotheses, we consider a number of dimensions of long-termism in this paper: ownership stability (H1), firm transition ( $\mathrm{H} 1)$, managerial exits $(\mathrm{H} 2)$, and equity share $(\mathrm{H} 3)$; and we adopt the index 
developed in Kappes and Schmid (2013) as a general measure of some other dimensions of long-termism (H4). Table 1 provides an overview of the long-termism variables used in our analyses, and Table 2 presents the descriptive statistics for the dependent variables as well as the independent and control variables. Outside the regression framework, we estimate survival functions for foundation-owned firms and other firms, respectively (H5).

[Please insert Table 1 here]

[Please insert Table 2 here]

In our first set of regressions, we examine Ownership stability as measured by the standard deviation of the largest owner's ownership stake over the sample period. We use the ownership stake of the foundation for foundation-owned firms, as this is the controlling owner according to the Business Authority, and the ownership stake of the largest shareholder for other firms. A variant of this measure was introduced in Elyasiani and Jia (2008) with the same motivation as here; namely that "it makes the second moment of the [...] ownership distribution an important dimension of the ownership influence" (op. cit.: 1771). The ownership stake in itself is weak as a measure of commitment, since (in principle) it tells us nothing about the intention to stay with the firm. The mean value of the ownership stability variable is 11.55 for foundation-owned firms and 14.95 for other firms, and the difference is statistically significant. If the direct subsidiary of an industrial foundation is a holding company, and the business activity is in a subsidiary to this company, we drop the holding company and keep its subsidiary (the operating company). In this case, we calculate the foundation's ownership stake as the product of ownership stakes along the chain.

The variable Firm transition is a dummy variable equal to 1 if the firm disappears from our data in a given year and is subsequently registered as closed. We identify a firm transition, which is a broader notion than bankruptcy, by whether or not the firm 
submit the mandatory financial reporting information and subsequently track changes in the legal status of the firm. In other words, we use the first year without financial data conditioned on a subsequent change in firm status from active to inactive. Using these criteria, 1.5 percent of the foundation-owned firms and 2.8 percent of the other firms in our sample experience a transition during the period. The difference is statistically significant.

The variable Manager exits is a count variable with information about the number of executive managers that have left the firm between year $t-1$ and year $t$. We do not know whether a separation is voluntary or forced. Small firms tend to have fewer managers and fewer exits. The average number of managers in our sample is 1.21 , and the average number of manager exits is 0.13 for foundation-owned firms and 0.07 for other firms. The difference is statistically significant and in the wrong direction compared to hypothesis 2 , but this turns out to be attributable to a higher number of managers in foundation-owned firms.

Theoretically, firm commitment encompasses both the depth of capital committed and the length of time for which it is committed (Mayer, 2013). Equity share is simply total equity over total assets. We argue that a higher equity share corresponds to a deeper capital commitment, meaning that more activities are financed by the shareholders' own money rather than being borrowed. As previously noted, foundations are legally obliged to preserve their capital, which in large part consist of stock in the companies they own. Moreover, their charters often mandate that they aim for the survival of the companies, which implies lower debt levels because debt increases the probability of default. These considerations point toward a financial conservatism and relatively high equity share in foundation-owned companies. The average equity share is 0.52 in foundation-owned firms, which is significantly higher than 0.42 in other firms. 
Finally, we use the Long-termism index developed by Kappes and Schmid (2013) with a few adjustments caused by data availability. ${ }^{3}$ The index varies from 0 to 1 , and higher values correspond to more long-term orientation. The average index value is 0.48 for foundation-owned firms and 0.46 in other firms. Following Kappes and Schmid (2013), we also define three sub-indices on mission-related investments, people-related investments, and external stakeholder-related investments.

Independent variable. The key independent variable in all our regressions is a dummy variable for Foundation ownership that takes the value 1 if a company has an owner that is listed in the Business Authority's register on controlling industrial foundations and 0 otherwise.

Control variables. We use the same set of control variables in all specifications. We control for (log) Total assets and (log) Number of employees. The combination of these two variables captures the labour intensity (Kappes and Schmid, 2013; Le Breton-Miller and Miller, 2006). We also control for Performance, the ratio of earnings before interest and taxes over total assets, and in all but the first specification we also control for Negative earnings, a dummy variable equal to 1 if EBIT is negative and 0 otherwise. We include performance information because low performance may, generally, be associated with low realizations of long-termism (Kappes and Schmid, 2013). All of the above control variables enter the regressions with their value lagged one year, and they are winsorized at the 1 percent level.

There are additional controls for some of the dependent variables: When we analyse ownership stability, we want to control for mean Ownership concentration, and when we analyse manager exits, we want to control for the Number of managers that can 
potentially exit the firm. Finally, we always add industry dummies based on the primary 2digit NACE industry in year $\mathrm{t}$ as well as year dummies.

\section{EMPIRICAL RESULTS}

Following Petersen (2009), we use pooled OLS regressions with standard errors corrected for heteroscedasticity and clustered at the firm level in the analyses of ownership stability, manager exits, and the long-termism index. The analysis of firm transitions is by logistic regression. Table 3 summarizes our findings.

[Please insert Table 3 here]

Ownership stability. In measuring this variable, we focus on the stability of the largest owner's ownership stake, as this person or company typically is the controlling entity. However, it should be acknowledged that in some firms, control is shared among multiple block holders (e.g. Edmans and Manso, 2011). In foundation-owned firms, the largest shareholder is an industrial foundation; in family-owned firms it is an individual or group of individuals, etc. We operationalize stability of ownership by calculating the standard deviation of the largest owner's ownership stake over the sample period, which means that our data collapses to one observation per firm on which we use the OLS estimator to examine the effect of foundation ownership. We have deliberately abstained from scaling the standard deviation by the mean ownership stake. The consequence of this is that a variation of say 10 percent results in a higher standard deviation when the ownership stake is lower. We wish to allow for this since such instability means more for the control or lack hereof when stakes are smaller. Instead, we include the mean ownership stake as a control variable. Table 4 present our results. 
[Please insert Table 4 here]

Our first observation in Model 1 in Table 4 is that the standard deviation is 3.5 percentage points lower in foundation-owned firms when compared to all other firms, suggesting more stable ownership in foundation-owned firms. However, variability does not imply unstable control per se; it is primarily a concern when it results from reductions in ownership stakes. Further analysis (not reported here) found that non-foundation-owned firms are more likely to experience reductions in the largest owner's stake. By implication, the higher standard deviation in these firms comes from "downside" variability, increasing uncertainty about the direction of the firm. The relationship between ownership stability and the largest shareholder's ownership stake differs between owners owning 100 percent of the firm and owners that have to share control with other owners. There is a small positive effect of the latter and a large negative effect of the former, which is unsurprising, since the standard deviation is equal to zero in these instances. Our data also shows us that firms with only one owner are prone to maintain this structure. We also note that relatively large and labour-intensive firms have lower variability. In Model 2, where only firms of similar size in terms of total assets are included, the negative and statistically significant coefficient estimate of the foundation-ownership dummy remains, although the standard deviation is only 2.7 percentage points lower in this case.

As we would expect, firms that are more profitable have more stable ownership structures. In fact, a non-foundation-owned firm with a one percentage point higher return on assets has about the same stability as the average foundation-owned firm. However, this effect is entirely driven by small firms, among which a good result allows for the status quo to continue but a bad result may threaten the capitalization of the firm and push the existing ownership to raise new equity or sell of (parts of) the firm. In Model 2, the performance effect disappears. Model 3 compares foundation-owned and family-owned firms to see if the 
foundation-effect is robust to this change in control group. A statistically significant point estimate of -2.6 tells us that this is indeed the case.

Firm transition. Firm transitions can be different things of which two of the most common are either closure following bankruptcy or mergers and acquisitions. The latter is closely related to the stability of ownership, which decrease in case of M\&A. Neither of the two are conducive for long-termism. Obviously, bankruptcy is a failure to keep the firm going; in a later subsection, we will look at this in a less dichotomous way by estimating survival functions. Mergers and acquisitions can be considered a failure of long-termism by way of lack of commitment (to unique firm values worth preserving) that opens up for either submitting these values to another controlling owner or blending (diluting) them with others in a more equal and friendly merger (Mayer, 2013). Table 5 presents our results.

\section{[Please insert Table 5 here]}

Model 1 in Table 5 provides the first estimates. This table reports results from a logistic regression, where the dependent variable is defined as described in the previous section. As expected, foundation ownership has a negative and statistically significant effect on the likelihood of firm transition compared to other firms. This is the result when compared to all other firms (Model 1) and size-similar firms (Model 2). Among the large firms, foundation ownership means even more; in fact, the coefficient estimate doubles. This effect disappears when foundation ownership is compared to family ownership (Model 3). Comparing Tables 4 and 5 along the family firm dimension, we can say that family firms have less stable ownership structures compared to foundation-owned firms, but that this does not translate to a higher likelihood of transition. In all specifications except Model 2, there is a negative relation between transition and firm size, when approximated by the value of all the assets, and between transition and firm performance. It is in line with standard empirical 
findings that larger firms are less likely to default (e.g. Shumway, 2000), and when it comes to mergers and acquisitions, it is also more likely that larger firms are the continuing entities, in which case the firm identification number remains and we do not register a transition.

As we would expect, better performing firms are less likely to either close down or sell out. This holds for all sub-samples except the large firms, where the coefficient is positive and marginally significant; success makes for attraction. However, for a given size and profitability, transition likelihood is reduced by foundation ownership. When significant, firm size, measured by the number of employees, has a positive effect, but - as mentioned this effect should be evaluated jointly with total assets, and F-tests show that the joint effect is negative and significant. Table 5 includes a variable indicating whether last year's earnings were negative. This variable is of course related to the performance variable (there is a negative correlation between the two by construction) but its dichotomous nature allows us to explicitly assess the response to negative earnings, assuming there is a separate effect of "red numbers" irrespective of the firm's cost of capital, which would otherwise rationally serve as the appropriate demarcation of good and bad performance. This variable is identical to the loss variable in Kappes and Schmid (2013), where it serves as a proxy for the pressure on a firm's bottom line in a given year. Throughout, negative earnings increase the likelihood of transition. When we examine whether foundation ownership moderates this relationship, we find that this is not the case.

Manager exits. The dependent variable here is the number of managers that have left the firm from year $\mathrm{t}-1$ to year $\mathrm{t}$, and the estimator used in the regression is pooled OLS. There is an observable firm characteristic that is relevant to include in the specifications for this particular dependent variable; namely the number of managers in the firm. We have to control for the simple fact that more managers can leave the firm when there are more managers employed in the firm. We can see in our data that there are more managers, on 
average, in foundation-owned firms, so failing to control directly for the number of managers would bias the estimated effect of foundation ownership. Table 6 presents our results.

[Please insert Table 6 here]

In Model 1, there is a negative and statistically significant relationship between foundation ownership and the number of manager exits. In other words, managers in firms owned by an industrial foundation are less likely to leave their firms. This is the result in all three specifications. In Model 3, where the control group is family firms, the foundation effect is still negative but less when compared to other firms with different owner characteristics; in fact, it is less than half. This again underlines the similarities between foundation-owned firms and family-owned firms. As expected, more managers exit when there are more managers in the firm. The other control variables also come out as expected: managers in larger firms are more likely to stay in their position; if not because of their skills and performance or an entrenched position, then simply because larger firms are less likely to experience a transition, cf. the previous sub-section. In firms with better performance, there are also fewer managers that exit. The performance sensitivity is especially high in larger firms as the coefficient estimate in Model 2 shows, and it is relatively low for foundationowned and family-owned firms. Disregarding the level of profitability and only focusing on whether it is positive or negative, we see that negative earnings in year $\mathrm{t}-1$ makes it more likely that one or more managers are not around by the end of year t. Looking at the interaction term, we see that the reaction to negative earnings is more severe when the controlling owner is an industrial foundation. This is not the case compared to large firms, but compared to other firms and especially family-owned firms, the foundation board, which is responsible to the company charter, appears to react swiftly to negative performance. One explanation may be that owner-managers find it particularly difficult to replace themselves or their family members (Sponholtz, 2006), while this may be easier in foundation-owned firms. 
Equity share. The hypothesis is that foundation-owned firms operate with less debt and more equity. Holding equity can serve as a long-term commitment to the firm, where the commitment according to Mayer (2013) can be measured from the depth of the committed capital, i.e. how much equity there is, and the length of time for which it is committed, i.e. how durable the commitment is in the face of adversity, or, in other words, how likely it is that the firm will be sold off. We know from above that firm transition is less likely for foundation-owned firms. If there is also more equity in these firms, there is a strong commitment. Our approximation of the depth of the committed capital is the equity share. The equity share reflects how much the shareholders have invested in the firm plus how much have been added by retained earnings. A high equity share includes any profits accumulated for the purpose of reducing financial vulnerability. Table 7 shows our results.

\section{[Please insert Table 7 here]}

In Model 1, the coefficient estimate for the dummy variable for foundation ownership is 0.11 , meaning that on average, and after controlling for observable firm characteristics, foundation-owned firms hold 11 percentage points more equity - relative to assets - than other firms. The average equity share in the sample is 0.42 , which implies that for an average equity share the share of equity to assets would increase by $0.11 / 0.42=26$ percent if the controlling owner changed from not being an industrial foundation to being an industrial foundation. The effect is smaller (0.08) when comparing among large firms and smallest (0.06) when compared to family firms. In Model 1, where the comparison is to all other firms, which is predominantly smaller firms, it is unsurprising that the difference is so large. In the classical empirical capital structure paper by Rajan and Zingales (1995), firm size has a strong positive effect on leverage, which is in line with our result of a smaller impact of foundation ownership in larger firms. However, the positive effect of foundation ownership remains significant in Model 2. In this specification, firm assets have a significant, 
positive effect, although moderated by the number of employees. In line with existing literature there is a positive relationship between profitability and equity share. The Myers and Majluf (1984) explanation would be that firms prefer to self-finance with internal funds rather than to issue debt or borrow. Relatedly, the dummy variable for negative earnings always comes out negative. The reaction to negative earnings by industrial foundations, as measured by the interaction term, is insignificant in all specifications except for Model 3. The positive and significant coefficient estimate suggests that foundations may be better than families at compensating for the write-down of equity that follows from negative earnings.

Long-termism index. The dependent variable in these regressions is the longtermism index developed in Kappes and Schmid (2013), which "categorized firms [...] according to their relative degrees of long-term orientation" (op. cit.: 552). The index ranges from 0.1 to 1 , where firms scoring closer to 0 are less long-term oriented than those scoring closer to 1 . The interesting innovation with this index is that it provides a broader and multifaceted assessment of corporate time horizons which goes beyond commonly used indicators such as R\&D expenditures, and at the same time allows for substitution effects between the different dimensions of long-termism. There are nine dimensions in the index covering investments, employees, and financing, where only the latter has a (weak) relation to the dimensions that we have already covered. In other words, this index adds perspectives to the long-termism measures that we have considered so far. More specifically, it provides an assessment of the long-term orientation that is much closer to business operations than the structural variables already covered. One way to think about the contribution of this index to our work is that it covers governance issues largely dealt with by management, whereas the other dimensions cover issues largely dealt with by either owners or the board. In Kappes and Schmid (2013), the average index value is 0.56 for all firms and 0.59 and 0.54 for familyowned firms and other firms, respectively. In our data, the index has an average value of 0.48 
for foundation-owned firms compared to 0.46 for other firms. Although small, the difference is significantly different from zero.

[Please insert Table 8 here]

Our hypothesis is that foundation ownership has a positive effect on the longtermism index, and this is indeed what we find across all specifications, although the effect is generally small. The fact that this result lines up nicely with our other results could suggest that the intention of the index fits well with another but related type of owner than a family. In Model 1 in Table 8 , the coefficient estimate of foundation ownership is 0.01 . With an overall average of 0.46 , this is a small effect but not far from what Kappes and Schmid (2013) find for German family firms, where the family business coefficient estimate is 0.03 or 0.02 depending on the definition of a family firm, and where the overall mean of the index is 0.56 . The effect is lower when foundation ownership is compared to other large firms (Model 2), and it is in-between in Model 3 when foundation-owned firms are compared to family firms. In all specifications, there is a positive and statistically significant effect of foundation ownership. Still comparing with family firms, there is a much stronger reaction to negative earnings in foundation-owned firms. According to this index, negative earnings reduce the long-term orientation more in foundation-owned firms than in family firms, or in any other firm in our sample, except for the large firms in Model 2, where the coefficient estimate is insignificant. Firm size has a positive effect on the index as does profitability, supporting the Myers and Majluf (1984) explanation that high profitability creates financial slack for (long-term) investments. Somehow contradictory to this, the negative earnings dummy comes out positive. To the extent that this variable approximates a crisis that puts pressure on the long-term orientation of the firm, we would expect it to come out negative, which is only the case for the interaction term with the foundation-ownership dummy. However, the joint effect is negative and significant. 
As briefly mentioned above, the long-term index is comprised of three categories, each covered by three variables specific to that category. This allows for calculating sub-indices for investment-related, employee-related, and financing-related variables, respectively, and for examining in more detail whether foundation-ownership is perhaps orientated towards particular elements of long-termism. The sub-indices are constructed so that the interpretation is similar to that of the aggregate index, i.e. firms scoring closer to 1 are more long-term oriented. In our data, there is relatively much variation between sub-indices but not between foundation-owned and other firms within sub-indices, although the differences are statistically significant in all instances with foundation-owned firms scoring highest. The investment sub-index has the lowest average value (standard deviation) of $0.34(0.14)$. This low value is partly attributable to relatively poor coverage of the R\&D expenditure variable among unlisted firms in our data, which biases our measurement towards 0 . The overall average (standard deviation) for the employee sub-index is $0.47(0.11)$, and for the financing sub-index $0.55(0.17)$. Panels A-C in Table 9 present the multivariate results. The foundation-ownership dummy is found to increase the long-term orientation along the financing dimension and the investment dimension, but only when compared to all other firms and never when compared to family firms. For the financing dimension, we also note that foundations mitigate adverse effects of financial pressure as approximated by the negative earnings dummy, even when compared to family firms, who have previously been found to maintain their long-run focus when facing short-term pressure (Kappes and Schmid, 2013).

[Please insert Table 9 here]

Longevity. The best indicator of long-termism may be survival of long-term oriented firms vis-à-vis other firms. In fact, this may be the ultimate evaluation of the 
viability of this approach, at least to the extent that ownership is about more than profit maximization.

To this end, we estimate Kaplan-Meier survival functions. Our data is subject to right-censoring, i.e. for some firms we only know at least how many years they survived. In the analysis of firm survival, we thus estimate the probability of survival up to time t, using the Kaplan-Meier survival function estimator. This gives us an estimate of the unconditional probability of survival beyond year $t$ as a function of firm age. Estimation is carried out by letting each type of ownership (foundation-owned firms and other firms) define a stratum and setting the event equal to firm transition. We follow Chancharat et al. (2012) in treating firm transitions as non-survivors. In Figure 2, we plot the survival curves for both foundationowned firms and other firms; it can be seen, for example, that the probability of surviving beyond age 40 is 30 percent for foundation-owned firms and 10 percent for other firms. The survival probability is always higher for foundation-owned firms.

[Please insert Figure 2 here]

The differences are partly attributable to the life history of industrial foundations. Typically, a foundation is established when a founder donates equity in an existing company to it. In other words, business companies are not established with foundation ownership. The foundation structure may, for example, arise as a solution to succession problems when both the founder and the company have reached a mature age. In other cases, the foundation is established by bequest in the founder's will. For a typical entrepreneur, this could be some 30 years after the company was founded. The survival curves for foundation-owned firms therefore omit unsuccessful companies that were closed down or acquired before they could become foundation-owned. However, examination of the survival curves shows that foundation-owned firms have higher survival rates even after the 
first 30 years. Among the non-foundation-owned firms, 80 percent of the remaining population at age 30 is gone at age 60 , while only 30 percent of the foundation-owned population at age 30 is gone at age 60 .

\section{DISCUSSION AND CONCLUSIONS}

In this paper, we have proposed and found support for the hypothesis that long-term ownership commitment will influence corporate governance towards a longer time horizon. Long-term owners will rationally internalize a greater part of the corporate time axis and so have an obvious incentive to avoid wasteful short-termism. Since shareholders top the chain of command to the directors and executives, they also have the power to influence corporate governance. To test our hypotheses, we have used a unique Danish data set on a long-term ownership type, the industrial foundation, which is created by wealthy entrepreneurs to preserve their companies for posterity. We have shown empirically that foundation-owned companies are in fact more long-term than other companies in several respects: Their ownership structure is more stable, there are fewer firm transitions (M\&A or bankruptcy), management turnover is lower, their capital structures are more conservative, business (especially financial) decisions appear to be more long-term, and survival rates are higher than among firms in general. In other words, we have found support for all our hypotheses, although there are some instances where the difference to family firms is insignificant. More specifically, this is the case when we look at firm transitions and the long-termism sub-index for investments in R\&D. The consistency of our results seems to indicate that long-termism reflects a general concept, a corporate governance model, which is manifested over a range of behaviours. We speculate that long-termism may reflect a business orientation laid down by the founding entrepreneurs, which emphasizes financial sustainability over short-term 
earnings. This is similar to what we find in the literature on the long-termism of family firms, and foundation ownership may indeed be seen as an alternative succession model in which family members often continue to play a role as directors or executives.

Our results contribute to the research on industrial foundations. Given our contribution in this paper, it now seems clearer that competitive advantages related to patient long-run ownership may be one reason why foundation-owned are able to compete successfully with other ownership structures (Thomsen, 1996, 1999; Hermann and Franke, 2002; Thomsen and Rose, 2004; Dzansi, 2012). This important not just for the Nordic countries, but also to the regulation and governance of global foundation-owned companies like Robert Bosch, Mahle, Hershey, Tata, or Rolex.

Our findings also have implications that are relevant for long-term ownership more generally. To be sure, industrial foundations may be regarded as an element of the Nordic corporate governance model (Thomsen, 2016a, 2016b, 2016c). They grew out of a set of specific historical conditions, which cannot necessarily be replicated elsewhere, including high taxation of private wealth and strong social governance (e.g. low levels of corruption) (Thomsen, 2016b). However, their charter-bound ownership commitment provides a natural experiment by which we can study the consequences of long-term ownership. For example, stable long-term ownership may be an important determinant of the long-termism observed in family businesses. Family businesses that do not make such a commitment may not display the same long-term governance as has been observed for family businesses in general. It is conceivable that founding families may strengthen their ownership commitment by shareholder agreements, bylaws, dual class shares, family offices, holding companies, and family councils, in ways which parallel foundation ownership (Caspar, Dias, and Elstrodt, 2010). 
Our results are relevant for the growing literature on short-termism (Asker et al., 2011, 2015; Kaplan and Minton, 2012; Bhagat and Bolton, 2014; Ladika and Saunter, 2014; Reilly et al., 2016; Sampson and Sin, 2016; Souder et al., 2016) by pointing to longterm ownership as a possible remedy. Theoretically, short-termism reflects a market failure, in which decision-makers fail to internalize the future costs and benefits of their present decisions. Short-term owners, security traders in the words of Roe (2013), are unlikely to take the long run into account, except to the extent that it is manifested in current stock prices. In contrast, controlling, long-term owners bridge the present and the future through their continuous ownership and have both the incentives and the power to act to preserve their long-term interests. Foundation ownership is only one way to ensure long-term ownership, which could also be exercised by founding families, business groups, or financial block holders. If our research is correct, what matters is not only owner identity and ownership stake, but also the commitment, which the owners make to the company.

We contribute to the literature on corporate governance by pointing to foundation ownership as mechanism for ownership commitment, which we find to be associated with long-termism in corporate governance more generally. Our results highlight the important association between ownership and corporate time horizons and add nuances to it by emphasizing the connection between ownership and ownership commitment. This is similar to what Kappes and Schmid (2013) establish regarding long-termism in family-owned firms. In our case, the foundation (charter) lays down a specific long-term governance style.

Although we stress the fundamental importance of ownership, some unresolved questions regarding the direction of causality remain. The fact that foundation-ownership is a choice, an alternative to family ownership or sale of the company, invites speculation about selection effects. It seems very likely that there are indeed selection effects at work so that founders choose the foundation structure because they believe that it matches the nature of 
the company and their conception of corporate governance. In other words, the direction of causality could in part go from long-termism to foundation ownership rather than vice versa. Detecting causality would require a research design using instrumental methods, which should be a topic for future research. Moreover, while this paper has not examined the consequences for economic performance, a logical next step would be to further examine whether foundation-owned companies benefit financially from long-termism.

These research limitations have direct implications for policy. It is not clear what would happen if companies were forced to adopt foundation ownership or other longterm oriented ownership structures rather than adopting it when they believe that it is the best solution. Our best guess is that it would be problematic, since not all companies are suited to foundation ownership, which, among other things, requires a capital structure (an equity base) and a cash flow that can self-finance a large part of a firm's expansion. Furthermore, while we have found that foundation ownership is associated with long-termism, we have not examined whether long-termism is in fact associated with better long-term performance. Therefore, we do not conclude that foundation ownership or long-term ownership in general should be mandated by law for all firms. Rather, we make the more modest claim that companies and their shareholders should be allowed to self-select into foundation ownership or other long-term ownership structures.

We therefore advocate a level playing field in which alternative governance mechanisms can compete freely and fairly with the idea that more efficient governance mechanisms out-compete less efficient alternatives. Since companies vary in terms of business models and market conditions, we would expect a great deal of diversity in terms of governance arrangements, including time horizons. Based on our findings in this paper, we would expect foundation ownership, with its long-term characteristics, to be especially amenable to industries with long time horizons, including R\&D and asset intensive industries. 
The current barriers against long-term ownership are formidable. US law deliberately imposes heavy fines on foundations that have a controlling interest of 20 percent or more in a business company (Fleishman, 2001). Policy makers should therefore reconsider whether to remove barriers to foundation ownership. The same may apply to family firms, where inheritance and capital gains taxes may imply a barrier to long-term family ownership. In recent years, countries like Sweden and Norway have abolished inheritance taxes partly for this reason. We recognize that there are other policy issues as work here, including wealth and income distribution; our point is only that policy-makers should consider the role of longterm owners if they are serious about combatting short-termism. We do not believe that corporate ownership is currently on the agenda in any meaningful way. 
1 To be sure, there are also counter arguments to long-termism of family ownership (Reilly et al., 2016). Family-owned companies cannot to the same extent access stock markets and may therefore face higher costs of capital (Fama and Jensen, 1983, 1985). For example, Anderson, Duru, and Reeb (2012) find that family firms invest less in long-term projects and especially in R\&D. This is an argument that we will elaborate on later in relation to our hypothesis 4 .

${ }^{2}$ In Denmark, ownership is flagged for all owners with more than 5 percent of the votes or the capital. If there is an ownership link between an industrial foundation and a business firm, the link between the two is maintained irrespective of the ownership stake. This procedure is valid because the Business Authority only registers foundations with controlling influence, which may be below 50 percent, as industrial foundations (otherwise it is not under their supervision).

${ }^{3}$ These nine variables are: R\&D (a dummy variable for whether or not the firm reports R\&D costs), CapEx (the increase in total assets over value added between t-1 and t), Asset maturity (depreciations over value added.), Burden (the change in the number of employees over value added between $t-1$ and $t$.), Salaries (the change in the average wage cost per employee between t-1 and t), Downsizing (the percentage point change in the number of employees if negative, zero otherwise), Cash (highly liquid assets over total assets.), Liquidity (current assets over total assets), and Debt maturity (long-term debt over total debt). We refer to Kappes and Schmid (2013) for more on the theoretical considerations behind the construction of the index. Our adaptation is due to data availability. Specifically, we use value added instead of sales and use a dummy variable for R\&D instead of a continuous variable. The index is set to missing if there is missing information for more than seven out of the nine variables. The three sub-indices (more about them later) are only calculated for firm-years where all variables are available. 


\section{REFERENCES}

Anderson, R.C. and D.M. Reeb. 2003. Founding-family ownership and firm performance: Evidence from the S\&P 500. The Journal of Finance, 58: 1301-1328.

Ampenberger, M., Schmid, T., Achleitner, A.K., Kaserer, C. 2013. Capital structure decisions in family firms: Empirical evidence from a bank-based economy. Review of Management Science, 7: 247-275.

Asker, J., Farre-Mensa, J., and Ljungqvist, A. 2011. Comparing the investment behavior of public and private Firms. National Bureau of Economic Research, Working Paper No. 17394.

Asker, J., Farre-Mensa, J., and Ljungqvist, A. 2015. Corporate investment and stock market listing: A Puzzle. Review of Financial Studies, 28: 342-390.

Atanassov, J. and Kim, E.H. 2009, Labor and corporate governance: International evidence from restructuring. Journal of Finance, 64: 341-374.

Bair, S. 2011. Lessons of the financial crisis: The dangers of short-termism. Remarks to the National Press Club, Washington, D.C., June 24.

Bansal, P. and DesJardine, M. 2014. Business sustainability: It is about time. Strategic Organization, 12: 70-78.

Barry, K.D. and Katz, S.N. 1987. Foundations and ruling class elites. Daedalus, 116: 1-40.

Belenzon, S., Patacconi, A., and Zarutskie, R. 2016. Married to the firm? A large-scale investigation of the social context of ownership. Strategic Management Journal, 37: 26112638 .

Bennedsen, M., Fan, J.P., Jian, M., and Yeh, Y.H. 2015. The family business map: Framework, selective survey, and evidence from Chinese family firm succession. Journal of Corporate Finance, 33: 212-226.

Bhagat, S. and Bolton, B. 2014. Financial crisis and bank executive incentive compensation. Journal of Corporate Finance, 25: 313-341.

Bianco, M., Bontempi, M.E., Golinelli, R. and Parigi, G. 2013. Family firms' investments, uncertainty and opacity. Small Business Economics, 40: 1035-1058.

Bolton, P., Scheinkman, J., and Xiong, W. 2006. Executive compensation and short-termist behaviour in speculative markets. Review of Economic Studies, 73: 577-610.

Bushee, B.J. 1998. The influence of institutional investors on myopic R\&D investment behavior. Accounting Review, 73: 305-333.

Børsting, C. and Thomsen, S. 2016. Foundation ownership and labour. Oxford Review of Economic Policy. Forthcoming. 
Caspar, C., Dias, A.K., and Elstrodt, H-P. 2010. The five attributes of enduring family businesses. Mckinsey Quarterly, 1: 1-10.

Chancharat, N., Krishnamurti, C., and Tian, G. 2012. Board structure and survival of new economy IPO firms. Corporate Governance: An International Review, 20: 144-163.

Chemla, G., Habib, M.A., and Ljungqvist, A. 2007. An analysis of shareholder agreements. Journal of The European Economic Association, 5: 93-121.

Chen, X., Harford, J., and Li, K. 2007. Monitoring: Which institutions matter? Journal of Financial Economics, 86: 279-305.

Choi, S.B., Park, B.I., and Hong, P. 2012. Does ownership structure matter for firm technological innovation performance? The case of Korean firms. Corporate Governance: An International Review, 20: 267-288.

Chua, J.H., Chrisman, J.J., and Bergiel, E.B. 2009. An agency theoretic analysis of the professionalized family firm. Entrepreneurship Theory and Practice, 33: 355-372.

Collins, J. and Porras, J. 1997. Built to Last. New York. Harperbusiness.

Cremers, M., Pareek, A., and Sautner, Z. 2013. Stock duration and misevaluation. Working paper.

Cremers, M., Masconale, S., and Sepe, S.M. 2016. Commitment and entrenchment in corporate governance. Northwestern Law \& Econ Research Paper, No. 15-22.

Croce, R.D., Stewart, F., and Yermo, J. 2011. Promoting longer-term investment by institutional investors. OECD Journal Financial Market Trends, 12: 145-164.

Cyert, R.M. and March, J.G. 1963. A behavioral theory of the firm. Malden, MA: Blackwell 1992.

Das, T.K. 1987. Strategic-planning and individual temporal orientation. Strategic Management Journal, 8: 203-209.

de Geus, A. 1997. The living company: Growth, learning and longevity in business. London: Nicholas Brealey.

De Maere, J., Jorissen, A., and Uhlaner, L.M. 2014. Board capital and the downward spiral: Antecedents of bankruptcy in a sample of unlisted firms. Corporate Governance: An International Review, 22: 387-407.

Denis, D.J. and Atulya, S. 1999. Ownership and board structures in publicly traded corporations. Journal of Financial Economics, 52: 187-223.

DesJardine, M.R. 2015. Under pressure: The causal effect of financial analyst coverage on long-term capital investments. Working Paper. 
Desyllas, P. and Hughes, A. 2010. Do high technology acquirers become more innovative? Research Policy, 39: 1105-1121.

Dutta, P.K. and Radner, R. 1999. Market selection and the profit-maximization hypothesis. Review of Economic Studies, 66: 769-798.

Dutta, P.K. and Sundaram, R.K. 2001. Survival and the art of profit maximization. Review of Economic Design, 6: 429-446.

Dzansi, J. 2011. Foundations and investment performance: The role of non-financial motives. Global Economy and Finance Journal, 5: 58-78.

Edmans, A. and Manso, G. 2011. Governance through trading and intervention: A theory of multiple blockholders. The Review of Financial Studies, 24: 2395-2428.

Elyasiani, E. and Jia, J.J. 2008. Institutional ownership stability and BHC performance. Journal of Banking \& Finance, 32: 1767-1781.

European Council. 2016. EU Shareholders' rights in EU companies: Presidency strikes deal with Parliament. URL: http://www.consilium.europa.eu/en/press/press-releases/2016/12/16shareholders-rights-eu-companies/

Fleischmann, J. 2001. Public policy and philanthropic purpose - foundation ownership and control of corporations in Germany and the United States. In A. Schlüter, V. Then, and P. Walkenhorst (Bertelsmann Foundation) (Eds.), Foundations in Europe: Society, Management and Law: 372-408. London: Directory for Social Change.

Frederick, S., Loewenstein, G., and O'Donoghue, T. 2002. Time discounting and time preference: A critical review. Journal of Economic Literature, 40: 351-401.

Fink, L. 2016. URL: http://www.prisim.com/wp-content/uploads/2016/02/BlackRock-CEOLarry-Fink-letter-to-SandP-500-CEOs-Business-Insider.pdf.

García-Castro, R., Aguilera, R.V., and Ariño, M.A. 2013. Bundles of firm corporate governance practices: A fuzzy set analysis. Corporate Governance: An International Review, 21: 390-407.

Gnan, L., Montemerlo, D., and Huse, M. 2015. Governance systems in family SMEs: The substitution effects between family councils and corporate governance mechanisms. Journal of Small Business Management, 53: 355-381

Goergen, M., Renneboog, L., and Khurshed, A. 2006. Explaining the diversity in shareholder lockup agreements. Journal of Financial Intermediation, 15: 254-280.

Gong, J.J. and Wu, S.Y. 2011. CEO turnover in private equity sponsored leveraged buyouts. Corporate Governance: An International Review, 19: 195-209.

Gilding, M. 2005. Families and fortunes: Accumulation, management succession and inheritance in wealthy families. Journal of Sociology, 41: 29-45. 
Gordon, G. and Nicholson, N. 2008. Family wars: Stories and insights from famous family business feuds. Kogan Page, London.

Hansmann, H.B. 1980. The role of nonprofit enterprise. The Yale Law Journal, 5: 835-901.

Hansmann, H.B. and Thomsen, S. 2013. Managerial Distance and Virtual Ownership: The Governance of Industrial Foundations. Working Paper.

Hermann, M. and Franke, G. 2002. Performance and policy of foundation-owned firms in Germany. European Financial Management, 8: 261-279.

Hiebl, M.R.W. 2013. Risk aversion in family firms: What do we really know? Journal of Risk Finance, 14: 49-70.

Hill, C.W., Hitt, M.A., and Hoskisson, R.E. 1992. Cooperative versus competitive structures in related and unrelated diversified firms. Organization Science, 3: 501-521.

Holmstrom, B. and Milgrom, P. 1994. The firm as an incentive system. The American Economic Review, 84: 972-991.

Howell, J.W. 2017. The survival of the U.S. dual class share structure. Journal of Corporate Finance, 44: 440-450.

Jagannathan, R., Matsa, D.A., Meier, I., and Tarhan, V. 2014. Why do firms use high discount rates? Working Paper.

James, H.S. 1999. Owner as manager, extended horizons and the family firm. International Journal of the Economics of Business, 6: 41-55.

Jensen, M.C. 1986. Agency costs of free cash flow, corporate Finance, and takeovers. American Economic Review, 76: 323-329.

Johnson, S. 2015. Protectionist French law alarms investors. Financial Times, Feb. 22, 2015.

LaPorta, R., Lopez-de-Silanes, F., Shleifer, A., and Vishny, R.W. 1997. Trust in large organizations. American Economic Review Papers and Proceedings, 87: 333-338.

Ladika, T. and Sautner, Z. 2014. The effect of managerial short-termism on corporate investment. Working Paper.

Le Breton-Miller, I. and Miller, D. 2006. Why do some family businesses out-compete? Governance, long-term orientations, and sustainable capability. Entrepreneurship: Theory \& Practice, 30: 731-746.

Levinson, H. 1971. Conflicts that plague family businesses. Harvard Business Review.

Levinthal, D.A. and March, J.G. 1993. The Myopia of Learning, Strategic Management Journal, 14: 95-112. 
Kachaner, N., Stalk, G., and Bloch, A. 2012. What you can learn from family business. Harvard Business Review, 90: 102-106.

Kaplan, S.N. and Minton, B.A. 2012. How has CEO turnover changed? International Review of Finance, 2012: 57-87.

Kappes, I. and Schmid, T. 2013. The effect of family governance on corporate time horizons. Corporate Governance: An International Review, 21(6): 547-566.

Kay, J. 2012. The Kay review of UK equity markets and long-term decision making. Final Report. URL:

https://www.gov.uk/government/uploads/system/uploads/attachment_data/file/253454/bis12-917-kay-review-of-equity-markets-final-report.pdf

Kim, Y., Lixin, S., and Zhu, X. 2016. Does quarterly earnings guidance cessation reduce investors' short-termism? Review of Accounting Studies, Forthcoming.

Kotlar, J., and De Massis, A. 2013. Goal setting in family firms: Goal diversity, social interactions, and collective commitment to family-centered goals. Entrepreneurship: Theory \& Practice, 37: 1263-1288.

Kreps, D.M. 1990. Corporate culture and economic theory. Mimeo. Graduate School of Business, Stanford University. In J.E. Alt and K.A. Shepsle (Eds.), Perspectives on positive political economy: 90-143. Cambridge University Press: New York.

Marginson, D. and McAulay, L. 2008. Exploring the debate on short-termism: A theoretical and empirical analysis. Strategic Management Journal, 29: 273-292.

Martin, K. and McConnell, J. 1991. Corporate performance, corporate takeovers, and management turnover. The Journal of Finance, 46: 671-687.

Mayer, C. 2013. Firm Commitment. Why the corporation is failing us and how to restore trust in it. Oxford University Press. Oxford.

Mayer, R.C., Davis, J.R., and Schoorman, F.D. 1995. An integrative model of organizational trust. Academy of Management Journal, 20: 709-737.

McKinsey \& Co. 2015. Perspectives on the Long Term 2015 Building a Stronger Foundation for Tomorrow.

Milliband, E. 2012. Our toxic blend of capitalism and short-termism. Financial Times January 18.

Milston, M.J. and Cohn, T. 1967. Personal and business aspects of stockholder agreements. Journal of Accountancy, 124: 41-45.

Mischel, W. 2014. The marshmallow test: Mastering self-sontrol. New York: Little, Brown and Company. 
Mischel, W. and Ebbesen, E.B. 1970. Attention in delay of gratification. Journal of Personality and Social Psychology, 16: 329-337.

Mischel, W., Shoda, Y., and Rodriguez, M.L. 1989. Delay of gratification in children. Science, 244: 933-938.

Mischel, W. and Ayduk, O. 2004. Willpower in a cognitive-affective processing system: The dynamics of delay of gratification. In R.F. Baumeister and K.D. Vohs (Eds.), Handbook of Self-Regulation: Research, Theory, and Applications: 99-129. New York: Guilford.

Myers, S.C. and Majluf, N.S. 1984. Corporate financing and investment decision when firms have information that investors do not have. Journal of Financial Economics, 13: 187-221.

Opler, T.C. and Titman, S. 1994. Financial distress and corporate performance. Journal of Finance, 49: 1015-1040.

Oprea, R. 2014. Survival versus profit maximization in a dynamic stochastic experiment. Econometrica, 82: 2225-2255.

Palley, T.I. 1997. Managerial turnover and the theory of short-termism. Journal of Economic Behavior \& Organization, 32: 547-557.

Petersen, M.A. 2009. Estimating standard errors in finance panel data sets: Comparing approaches. Review of Financial Studies, 22: 435-480.

Phelps, E.S. 2010, Shorttermism is undermining America. New Perspectives Quarterly, 27: 17-19.

Poterba, J.M. and Summers, L. 1995. A CEO survey of U.S. companies' time horizons and hurdle rates. Sloan Management Review, 37: 43-53.

Prencipe, A., Bar-Yosef, S., Mazzola, P., and Pozza, L. 2011. Income smoothing in familycontrolled companies: Evidence from Italy. Corporate Governance: An International Review, 19: 529-546.

Radner, R. 1998. Economic Survival. In D.P. Jacobs et al. (Eds.), Frontiers of Research in Economic Theory: 183-209. Cambridge: Cambridge University Press.

Rajan, R.G. and Zingales, L. 1995. What do we know about capital structure? Some evidence from international data. The Journal of Finance, 50: 1421-1460.

Reilly, G., Souder, D. and Ranucci. R. 2016. Time horizon of investments in the resource allocation process: Review and framework for next steps. Journal of Management, 42: 1169-1194.

Reuben, E., Sapienza, P., and Zingales, L. 2015. Procrastination and impatience. Journal of Behavioral and Experimental Economics, 58: 63-76. 
Reuters. 2015. Clinton proposes tax, buyback changes to encourage long-term growth. July 24.

Roe, M.J. 2013. Corporate short-termism - In the boardroom and in the courtroom. Harvard Public Law Working Paper No. 13-18.

Sampson, R.C. and Shi, Y. 2016. Evidence and implications of short-termism in US public capital markets: 1980-2013. Working Paper.

Schelling, T.C. 1960. The Strategy of Conflict, Harvard University Press.

Schellling, T.C. 1985. Strategies of commitment and other essays. Harvard University Press.

Schleifer, A., and Vishny, R.W. 1990. Equilibrium short horizons of investors and firms. American Economic Review, 80: 148-153.

Shumway, T. 2000. Forecasting bankruptcy more accurately: A simple hazard model. The Journal of Business, 74: 101-124.

Slawinski, N. and Bansal, P. 2012. What's time got to do with it? Understanding temporal perspectives in organizational responses to climate change. Organization Studies, 33: 15371563.

Solomon, S.D. 2015. France answers hostile bids with the two-vote Share. New York Times, May 19.

Souder, D. and Bromiley, P. 2012. Explaining temporal orientation: Evidence from the durability of firms' capital investments. Strategic Management Journal, 33: 550-569.

Souder, D. and Shaver, J.M. 2010. Constraints and incentives for making long horizon corporate investments. Strategic Management Journal, 31: 1316-1336.

Souder, D., Reilly, G., Bromiley, P., and Mitchell, S. 2016. A behavioral understanding of investment horizon and firm performance. Organization Science, 27: 5-12

Sponholtz, C. 2006. Determinants of CEO turnover in public and private firms in Denmark CEO and firm characteristics. Working Paper.

Stein, J.C. 1988. Takeover threats and managerial myopia. Journal of Political Economy, 96: 61-80.

Stein, J.C. 1989. Efficient capital markets, inefficient firms: A model of myopic corporate behavior. Quarterly Journal of Economics, 104: 655-669.

Stiglitz, J.E. 2016. An agenda for sustainable and inclusive growth for emerging markets, Journal of Policy Modeling, 38: 693-710.

Tait, A.A. 2015. The secret economy of charitable giving. Boston University Law Review, Vol. 95. 
Taylor, L.A. 2010. Why are CEOs rarely fired? Evidence from structural estimation, Journal of Finance, 65: 2051-2087.

Thakor, A.V. 1990. Investment "myopia" and the internal organization of capital allocation decisions. Journal of Law, Economics, \& Organization, 6: 129-154.

Thanassoulis, J.E. 2013. Industry structure, executive pay, and short-termism. Management Science, 59: 402-419.

Thanassoulis, J.E. and Somekh, B. 2016. Real economy effects of short-term equity ownership. Journal of International Business Studies, 47: 233-254.

Thaler, R.H. 1981. Some empirical evidence on dynamic inconsistency. Economics Letters, 8: 201-207.

Thaler, R.H., Tversky, A., Kahneman, D., and Schwartz, A. 1997. The effect of myopia and loss aversion on risk taking: An experimental test. The Quarterly Journal of Economics, 112: 647-661.

Thomsen, S. 1996. Foundation ownership and economic performance. Corporate Governance: An International Review, 4: 212-221.

Thomsen, S. 1999. Corporate ownership by industrial foundations. European Journal of Law and Economics, 7: 117-136.

Thomsen, S. and Rose, C. 2004. Foundation ownership and financial performance. The European Journal of Law and Economics, 18: 343-364.

Thomsen, S. and Degn, S.M. 2014. The charters of industrial foundations. Working Paper.

Thomsen, S. 2016a. Industrial foundations: The Danish model, in A. Simonyi and D. Cagan (Eds.), Nordic Ways: 3-33. Brookings Institution Press, October 25, 2016.

Thomsen, S. 2016b. The Nordic corporate governance model. Management and Organization Review, 12: 4-12.

Thomsen, S. 2016c. Nordic corporate governance revisited. The Nordic Journal of Business, 65: 189-204.

Thomsen, S. 2017. The Danish industrial foundations. Copenhagen: DJOEF Publishing Company.

Uhlaner, L., Floren, R., and Geerlings, J. 2007. Owner commitment and relational governance in the privately-held firm: An empirical study. Small Business Economics, 29: 275-293.

Villalonga, B. and Amit, R. 2006. How do family ownership, control and management affect firm value? Journal of Financial Economics, 80: 385-417. 
Wang, H.C., Zhao, S., and He, J. 2015. Increase in takeover protection and firm knowledge accumulation strategy. Strategic Management Journal, Forthcoming.

White, W.S., Krinke, T.D., and Geller, D.L. 2004. Family business succession planning: Devising an overall strategy. Journal of Financial Service Professionals, 58: 67-86.

Wilson, N., Wright, M., and Scholes, L. 2013. Family business survival and the role of boards. Entrepreneurship: Theory \& Practice, 37: 1369-1389.

Woidtke, T. 2002. Agents watching agents? Evidence from pension fund ownership and firm value. Journal of Financial Economics, 63, 99-131.

Zellweger, T.M. 2007. Time horizon, costs of equity capital, and generic investment strategies of firms. Family Business Review, 20: 1-15.

Zellweger, T., and Kammerlander, N. 2015. Family, wealth, and governance: An agency account. Entrepreneurship: Theory \& Practice, 39: 1281-1303.

Zhang, Y. and Gimeno, J. 2016. Earnings pressure and long-term corporate governance: Can long-term-oriented investors and managers reduce the quarterly earnings obsession? Organization Science, 27: 354-372. 
Figure 1. The foundation governance bundle. Our hypotheses

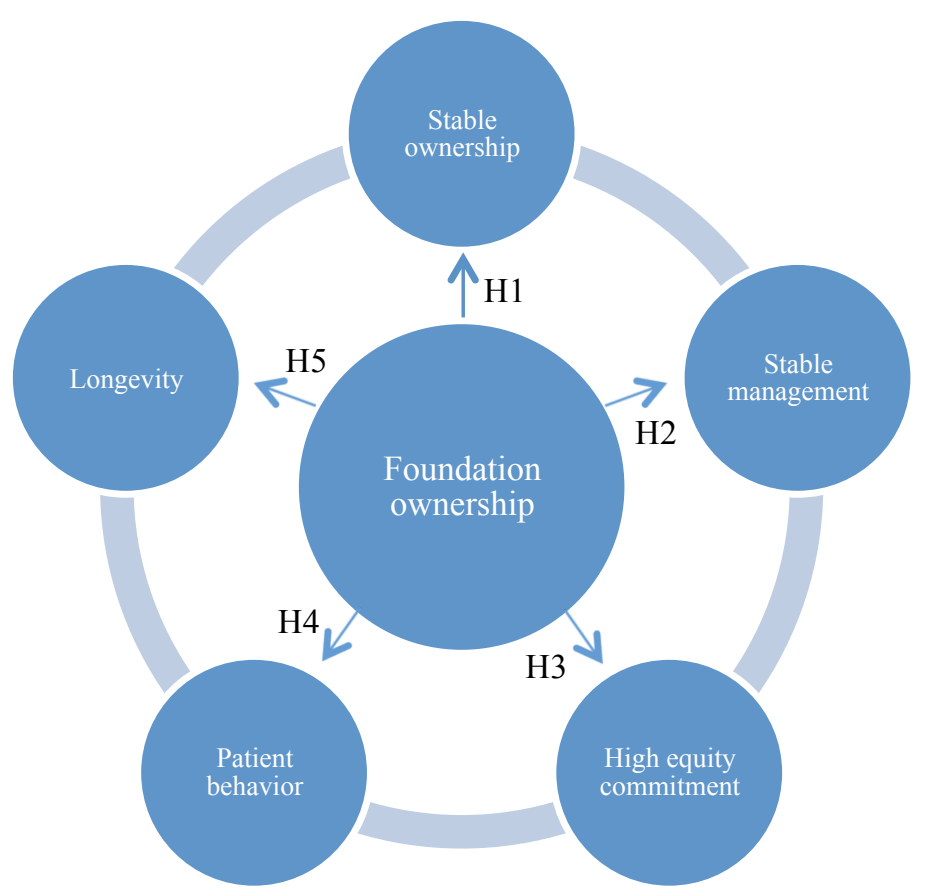


Figure 2. Kaplan-Meier survival curves for foundation-owned firms and other firms

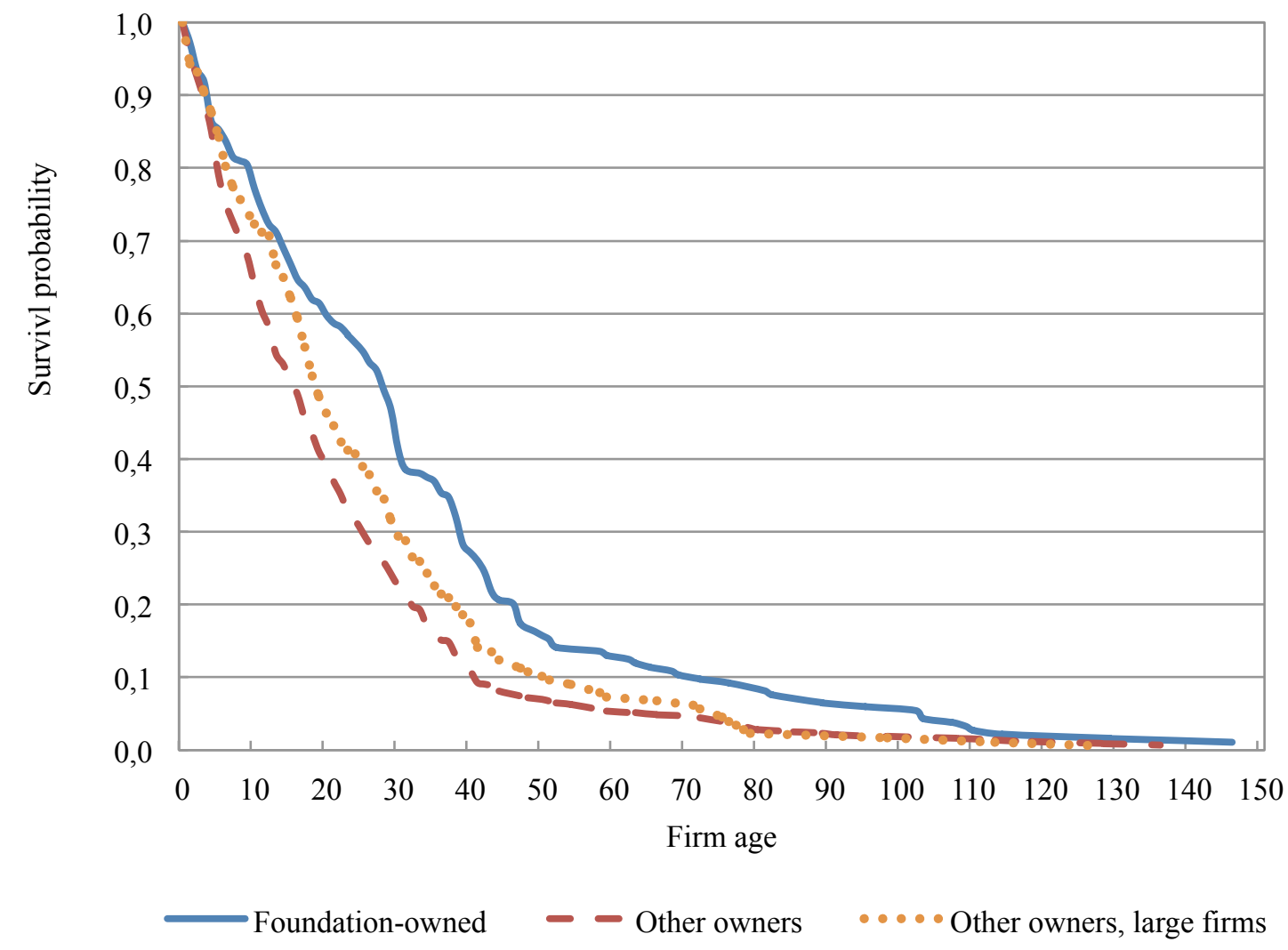


Table 1. Long-termism variables

\begin{tabular}{|c|c|c|}
\hline Variable & Description & Rationale \\
\hline Ownership stability & $\begin{array}{l}\text { Standard deviation of the } \\
\text { largest owner's ownership } \\
\text { stake over the sample period. }\end{array}$ & $\begin{array}{l}\text { Low value indicates a stable } \\
\text { and more persistent owner } \\
\text { with long-term orientation. }\end{array}$ \\
\hline Firm transition & $\begin{array}{l}\text { Dummy variable equal to one } \\
\text { if a firm leaves our financial } \\
\text { data in year } t \text { and its status } \\
\text { subsequently changes from } \\
\text { active to inactive. }\end{array}$ & $\begin{array}{l}\text { Value equal to zero means that } \\
\text { a firm continues as an } \\
\text { independent entity that can } \\
\text { pursue the long-term interests } \\
\text { of the controlling owner. }\end{array}$ \\
\hline Manager exit & $\begin{array}{l}\text { Count variable equal to the } \\
\text { number of officers that } \\
\text { separate from a firm between } \\
\text { year } \mathrm{t}-1 \text { and year } \mathrm{t} \text {. }\end{array}$ & $\begin{array}{l}\text { Low value indicates stable } \\
\text { management aligned with the } \\
\text { long-term orientation of the } \\
\text { controlling owner. }\end{array}$ \\
\hline Equity share & $\begin{array}{l}\text { Total equity relative to total } \\
\text { assets in year } t \text {. }\end{array}$ & $\begin{array}{l}\text { High value indicates that more } \\
\text { of the owners' capital is } \\
\text { committed to a firm's long- } \\
\text { term interests. }\end{array}$ \\
\hline Survival & $\begin{array}{l}\text { Estimated survival probability } \\
\text { by the end of our sample } \\
\text { period as a function of firm } \\
\text { age using the Kaplan-Meier } \\
\text { method. }\end{array}$ & $\begin{array}{l}\text { High value indicates that a } \\
\text { firm's strategy is robust to } \\
\text { changes over time in the } \\
\text { business environment. }\end{array}$ \\
\hline \multicolumn{3}{|l|}{ Long-termism index (LTI) } \\
\hline - Overall & $\begin{array}{l}\text { A measure of the rank of a } \\
\text { firm in year } t \text { across the nine } \\
\text { long-termism variables } \\
\text { identified in Kappes and } \\
\text { Schmid (2013). Scaled to fit a } \\
\text { range between zero and one. }\end{array}$ & $\begin{array}{l}\text { High value indicates long- } \\
\text { termism by way of relatively } \\
\text { generous investments in a } \\
\text { firm's mission and } \\
\text { stakeholders. }\end{array}$ \\
\hline - Investments & $\begin{array}{l}\text { Sub-index focusing on } \\
\text { variables related to the } \\
\text { activities and assets of the } \\
\text { firm in year t. }\end{array}$ & $\begin{array}{l}\text { High value indicates long- } \\
\text { term focus on a firm's } \\
\text { investments to realize the } \\
\text { mission of the firm. }\end{array}$ \\
\hline - Employees & $\begin{array}{l}\text { Sub-index focusing on } \\
\text { variables related to the } \\
\text { employees of the firm in year } \\
\text { t. }\end{array}$ & $\begin{array}{l}\text { High value indicates long- } \\
\text { term focus on a firm's } \\
\text { investments in and relations to } \\
\text { employees. }\end{array}$ \\
\hline - $\quad$ Financing & $\begin{array}{l}\text { Sub-index focusing on } \\
\text { variables related to the cash } \\
\text { flow and financing of the firm } \\
\text { in year } t \text {. }\end{array}$ & $\begin{array}{l}\text { High value indicates long- } \\
\text { term focus on a firm's } \\
\text { relationship to its suppliers as } \\
\text { well as the long-term aspects } \\
\text { of its financing. }\end{array}$ \\
\hline
\end{tabular}


Table 2. Descriptive statistics

\begin{tabular}{|lrrr|}
\hline & \multicolumn{1}{l}{ Mean } & \multicolumn{1}{l}{ Std. dev. } & Median \\
\hline Ownership stability & 14.931 & 18.701 & 0.000 \\
Firm transition & 0.028 & 0.164 & 0.000 \\
Managerial exits & 0.067 & 0.284 & 0.000 \\
Equity share & 0.417 & 0.307 & 0.358 \\
LTI & 0.458 & 0.126 & 0.460 \\
Total assets & 72,110 & $1,960,228$ & 5,421 \\
Number of employees & 44.836 & 880.314 & 6.000 \\
Performance & 0.044 & 0.165 & 0.035 \\
Negative earnings & 0.278 & 0.448 & 0.000 \\
Largest ownership stake & 42.958 & 46.455 & 5.000 \\
Full ownership & 0.156 & 0.363 & 0.000 \\
Number of managers & 1.211 & 0.528 & 1.000 \\
\hline
\end{tabular}

Ownership stability is the standard deviation of the largest owner's ownership stake over the sample period. Firm transition is a dummy variable equal to 1 if the firm disappears from our financial data in a given year and subsequently is registered as closed and 0 otherwise. Managerial exits is a count variable equal to the number of C-suite managers that have left the firm between year t-1 and year t. Equity share is the ratio between total equity and total assets. Long-termism Index (LTI) is an adapted version of the long-termism index in Kappes and Schmid (2013). Total assets is the book value of total assets in 1000 DKK. Number of employees is the number of full-time employees. Performance is the ratio of earnings before interest and taxes over total assets. Negative earnings is a dummy variable equal to 1 if EBIT is negative and 0 otherwise. Largest ownership stake is the average ownership stake of the largest owner over the sample period. Full ownership is a dummy variable equal to 1 if the largest owner owns one hundred percent of the firm throughout the period. Number of managers is the number of $\mathrm{C}$-suite managers in the firm in year $\mathrm{t}$. 
Table 3. Summary of findings

\begin{tabular}{|c|c|c|c|c|}
\hline & Hypothesis & \multicolumn{3}{|c|}{ Compared to: } \\
\hline & & All firms & Large firms & Family firms \\
\hline H1 & $\begin{array}{l}\text { Foundation ownership will be more } \\
\text { stable than ownership by other } \\
\text { controlling shareholders }\end{array}$ & $\begin{array}{l}\text { Not rejected } \\
\text { at the } 1 \% \\
\text { level }\end{array}$ & $\begin{array}{l}\text { Not rejected } \\
\text { at the } 1 \% \\
\text { level }\end{array}$ & $\begin{array}{l}\text { Not rejected } \\
\text { at the } 5 \% \\
\text { level }\end{array}$ \\
\hline & $\begin{array}{l}\text { Alternatively: There are fewer firm } \\
\text { transitions (closures) amongst } \\
\text { foundation-owned companies }\end{array}$ & $\begin{array}{l}\text { Not rejected } \\
\text { at the } 5 \% \\
\text { level }\end{array}$ & $\begin{array}{l}\text { Not rejected } \\
\text { at the } 5 \% \\
\text { level }\end{array}$ & $\begin{array}{l}\text { Rejected at } \\
\text { the } 10 \% \\
\text { level }\end{array}$ \\
\hline $\mathrm{H} 2$ & $\begin{array}{l}\text { Foundation-owned companies will } \\
\text { have greater continuity of } \\
\text { management (fewer exits) than other } \\
\text { companies }\end{array}$ & $\begin{array}{l}\text { Not rejected } \\
\text { at the } 1 \% \\
\text { level }\end{array}$ & $\begin{array}{l}\text { Not rejected } \\
\text { at the } 1 \% \\
\text { level }\end{array}$ & $\begin{array}{l}\text { Not rejected } \\
\text { at the } 10 \% \\
\text { level }\end{array}$ \\
\hline H3 & $\begin{array}{l}\text { Foundation-owned firms have less } \\
\text { financial leverage and higher equity } \\
\text { ratios than other firms }\end{array}$ & $\begin{array}{l}\text { Not rejected } \\
\text { at the } 1 \% \\
\text { level }\end{array}$ & $\begin{array}{l}\text { Not rejected } \\
\text { at the } 1 \% \\
\text { level }\end{array}$ & $\begin{array}{l}\text { Not rejected } \\
\text { at the } 1 \% \\
\text { level }\end{array}$ \\
\hline H4 & $\begin{array}{l}\text { Foundation-owned firms will display } \\
\text { more long-term oriented business } \\
\text { behaviour than other firms }\end{array}$ & $\begin{array}{l}\text { Not rejected } \\
\text { at the } 1 \% \\
\text { level }\end{array}$ & $\begin{array}{l}\text { Not rejected } \\
\text { at the } 1 \% \\
\text { level }\end{array}$ & $\begin{array}{l}\text { Not rejected } \\
\text { at the } 1 \% \\
\text { level }\end{array}$ \\
\hline H5 & $\begin{array}{l}\text { Foundation-owned firms will survive } \\
\text { longer than other firms }\end{array}$ & Not rejected & Not rejected & Not rejected \\
\hline
\end{tabular}


Table 4. Foundation ownership and ownership stability

\begin{tabular}{|llll|}
\hline & Model 1 & Model 2 & Model 3 \\
\hline Foundation ownership & $-3.467 * * *$ & $-2.650^{* * *}$ & $-2.590^{* *}$ \\
Largest ownership stake & $(0.670)$ & $(0.966)$ & $(1.084)$ \\
& $0.145^{* * *}$ & $0.172^{* * *}$ & $0.181^{* * *}$ \\
Full ownership & $(0.005)$ & $(0.016)$ & $(0.011)$ \\
& $-32.746^{* * *}$ & $-31.689^{* * *}$ & $-27.247^{* * *}$ \\
Ln(total assets) & $(0.185)$ & $(0.640)$ & $(0.985)$ \\
Ln(number of employees) & $-0.391^{* * *}$ & -0.163 & $-0.816^{* * *}$ \\
& $(0.087)$ & $(0.273)$ & $(0.313)$ \\
Performance & $-0.206^{* *}$ & $-0.420^{* *}$ & $0.596^{* *}$ \\
Observations & $(0.091)$ & $(0.213)$ & $(0.299)$ \\
R-square & $-4.522^{* * *}$ & -0.363 & -3.746 \\
The dep & $(0.787)$ & $(3.198)$ & $(2.889)$ \\
\hline
\end{tabular}

The dependent variable is the standard deviation of the largest owner's ownership stake over the sample period. In Model 1, all observations in our data set are included. In Model 2, the sample is size-restricted to firms with more than 100 million DKK in total assets. In model 3, there are no size restrictions but the control group now consists of family firms. Foundation ownership is a dummy variable equal to 1 if the largest owner is an industrial foundation and 0 otherwise. Largest ownership stake is the average ownership stake of the largest owner over the sample period. Full ownership is a dummy variable equal to 1 if the largest owner owns one hundred percent of the firm throughout the period. Performance is the ratio of earnings before interest and taxes over total assets. Industry dummies are included in the estimations but not reported. All models are estimated as ordinary least squares regressions with standard errors corrected for heteroscedasticity. Robust standard errors are reported in the parentheses. $* * * \mathrm{p}<0.01,{ }^{* *} \mathrm{p}<0.05,{ }^{*} \mathrm{p}<0.1$. 
Table 5. Foundation ownership and firm transition

\begin{tabular}{|llll|}
\hline & Model 1 & Model 2 & Model 3 \\
\hline Foundation ownership & $-0.447^{* *}$ & $-0.861^{* *}$ & -0.336 \\
Ln(total assets) & $(0.227)$ & $(0.418)$ & $(0.237)$ \\
Ln(number of employees) & $-0.052^{* * *}$ & -0.077 & $-0.066^{* * *}$ \\
& $(0.013)$ & $(0.055)$ & $(0.025)$ \\
Performance & $0.045^{* * *}$ & -0.038 & $0.118^{* * *}$ \\
& $(0.014)$ & $(0.035)$ & $(0.024)$ \\
Negative earnings & $-0.650^{* * *}$ & $1.046^{*}$ & $-1.238^{* * *}$ \\
& $(0.094)$ & $(0.537)$ & $(0.187)$ \\
Foundation ownership*negative earnings & $0.535^{* * *}$ & $0.361^{* *}$ & $0.493 * * *$ \\
& $(0.035)$ & $(0.152)$ & $(0.060)$ \\
Observations & 0.041 & 0.102 & 0.020 \\
The dep & $(0.347)$ & $(0.845)$ & $(0.350)$ \\
\hline
\end{tabular}

The dependent variable is a dummy variable equal to 1 if the firm disappears from our financial data in a given year and subsequently is registered as closed and 0 otherwise. In Model 1, all observations in our data set are included. In Model 2, the sample is sizerestricted to firms with at least 100 employees. In model 3, there are no size restrictions but the control group now consists of family firms. Foundation ownership is a dummy variable equal to 1 if the largest owner is an industrial foundation and 0 otherwise. Performance is the ratio of earnings before interest and taxes over total assets. Negative earnings is a dummy variable equal to 1 if EBIT is negative and 0 otherwise. Industry and year dummies are included in the estimations but not reported. All models are estimated as pooled Logit models with standard errors clustered at the firm level and corrected for heteroscedasticity. Robust standard errors are reported in the parentheses. $* * * p<0.01, * * \mathrm{p}<0.05, * \mathrm{p}<0.1$. 
Table 6. Foundation ownership and manager exists

\begin{tabular}{|llll|}
\hline & Model 1 & Model 2 & Model 3 \\
\hline Foundation ownership & $-0.070^{* * *}$ & $-0.077^{* * *}$ & $-0.027^{*}$ \\
Number of managers & $(0.023)$ & $(0.026)$ & $(0.015)$ \\
Ln(total assets) & $0.420^{* * *}$ & $0.299^{* * *}$ & $0.359^{* * *}$ \\
& $(0.016)$ & $(0.029)$ & $(0.012)$ \\
Ln(number of employees) & $-0.003^{* *}$ & $-0.013^{*}$ & $-0.004^{* * *}$ \\
& $(0.001)$ & $(0.008)$ & $(0.002)$ \\
Performance & $-0.007^{* * *}$ & $-0.011^{* * *}$ & $-0.007^{* * *}$ \\
& $(0.001)$ & $(0.003)$ & $(0.001)$ \\
Negative earnings & $-0.075^{* * *}$ & $-0.125^{* * *}$ & $-0.046^{* * *}$ \\
Foundation ownership*negative earnings & $(0.008)$ & $(0.044)$ & $(0.014)$ \\
& $0.026^{* * *}$ & $0.063^{* * *}$ & $0.007^{* *}$ \\
Observations & $(0.002)$ & $(0.009)$ & $(0.003)$ \\
R-square & $0.086^{* * *}$ & 0.055 & $0.101^{* * *}$ \\
The deppend & $(0.027)$ & $(0.042)$ & $(0.023)$ \\
& 198,022 & 22,875 & 56,205 \\
\hline
\end{tabular}

The dependent variable is a count variable equal to the number of $\mathrm{C}$-suite managers that have left the firm between year t-1 and year t. In Model 1, all observations in our data set are included. In Model 2, the sample is size-restricted to firms with at least 100 employees. In model 3, there are no size restrictions but the control group now consists of family firms. Foundation ownership is a dummy variable equal to 1 if the largest owner is an industrial foundation and 0 otherwise. Number of managers is the number of $\mathrm{C}$-suite managers in the firm in year t. Performance is the ratio of earnings before interest and taxes over total assets. Negative earnings is a dummy variable equal to 1 if EBIT is negative and 0 otherwise. Industry and year dummies are included in the estimations but not reported. All models are estimated as pooled OLS models with standard errors clustered at the firm level and corrected for heteroscedasticity. Robust standard errors are reported in the parentheses. $* * * p<0.01, * *$ $\mathrm{p}<0.05, * \mathrm{p}<0.1$. 
Table 7. Foundation ownership and equity share

\begin{tabular}{|llll|}
\hline & Model 1 & Model 2 & Model 3 \\
\hline Foundation ownership & $0.107^{* * *}$ & $0.080^{* * *}$ & $0.064^{* * *}$ \\
Ln(total assets) & $(0.013)$ & $(0.019)$ & $(0.014)$ \\
Ln(number of employees) & $0.041^{* * *}$ & $0.024^{* * *}$ & $0.062^{* * *}$ \\
& $(0.001)$ & $(0.004)$ & $(0.002)$ \\
Performance & $-0.061^{* * *}$ & $-0.028^{* * *}$ & $-0.087^{* * *}$ \\
& $(0.001)$ & $(0.003)$ & $(0.002)$ \\
Negative earnings & $0.336^{* * *}$ & $0.452^{* * *}$ & $0.458^{* * *}$ \\
& $(0.006)$ & $(0.030)$ & $(0.009)$ \\
Foundation ownership*negative earnings & $-0.055^{* * *}$ & $-0.055^{* * *}$ & $-0.044^{* * *}$ \\
& $(0.002)$ & $(0.006)$ & $(0.003)$ \\
Observations & 0.023 & 0.037 & $0.037^{* *}$ \\
R-square & $(0.017)$ & $(0.024)$ & $(0.018)$ \\
\hline
\end{tabular}

The dependent variable is the ratio between total equity and total assets in year $\mathrm{t}$. In Model 1 , all observations in our data set are included. In Model 2, the sample is size-restricted to firms with at least 100 employees. In model 3, there are no size restrictions but the control group now consists of family firms. Foundation ownership is a dummy variable equal to 1 if the largest owner is an industrial foundation and 0 otherwise. Performance is the ratio of earnings before interest and taxes over total assets. Negative earnings is a dummy variable equal to 1 if EBIT is negative and 0 otherwise. Industry and year dummies are included in the estimations but not reported. All models are estimated as pooled OLS models with standard errors clustered at the firm level and corrected for heteroscedasticity. Robust standard errors are reported in the parentheses. $* * * \mathrm{p}<0.01, * * \mathrm{p}<0.05, * \mathrm{p}<0.1$. 
Table 8. Foundation ownership and the long-termism index

\begin{tabular}{|llll|}
\hline & Model 1 & Model 2 & Model 3 \\
\hline Foundation ownership & $0.012^{* * *}$ & $0.007^{* * *}$ & $0.010^{* * *}$ \\
Ln(total assets) & $(0.002)$ & $(0.002)$ & $(0.002)$ \\
Ln(number of employees) & $-0.001^{* * *}$ & $-0.014 * * *$ & $-0.001 * *$ \\
& $(0.000)$ & $(0.001)$ & $(0.000)$ \\
Performance & $0.007^{* *}$ & 0.003 & $0.016^{* * *}$ \\
& $(0.003)$ & $(0.009)$ & $(0.005)$ \\
Negative earnings & $0.010^{* * *}$ & 0.002 & $0.019^{* * *}$ \\
& $(0.002)$ & $(0.007)$ & $(0.003)$ \\
Foundation ownership*negative earnings & $0.008^{* * *}$ & -0.007 & $0.008^{* *}$ \\
& $(0.002)$ & $(0.009)$ & $(0.003)$ \\
Observations & $-0.019^{* * *}$ & -0.009 & $-0.049^{* * *}$ \\
R-square & $(0.000)$ & $(0.000)$ & $(0.000)$ \\
The & 336,419 & 24,888 & 129,999 \\
\hline
\end{tabular}

The dependent variable is an adapted version of the long-termism index in Kappes and Schmid (2013). In Model 1, all observations in our data set are included. In Model 2, the sample is size-restricted to firms with at least 100 employees. In model 3, there are no size restrictions but the control group now consists of family firms. Foundation ownership is a dummy variable equal to 1 if the largest owner is an industrial foundation and 0 otherwise. Performance is the ratio of earnings before interest and taxes over total assets. Negative earnings is a dummy variable equal to 1 if EBIT is negative and 0 otherwise. Industry and year dummies are included in the estimations but not reported. All models are estimated as pooled OLS models with standard errors clustered at the firm level and corrected for heteroscedasticity. Robust standard errors are reported in the parentheses. $* * * \mathrm{p}<0.01, * *$ $\mathrm{p}<0.05, * \mathrm{p}<0.1$. 
Table 9. Foundation ownership and the long-termism sub-indices

\begin{tabular}{|llll|}
\hline & Model 1 & Model 2 & Model 3 \\
\hline & \multicolumn{3}{c|}{ Panel A: Financing } \\
\hline Foundation ownership & $\begin{array}{l}0.040^{* * *} \\
(0.004)\end{array}$ & $\begin{array}{l}0.045^{* * *} \\
(0.004)\end{array}$ & $\begin{array}{l}0.040^{* * *} \\
\end{array}$ \\
\hline & \multicolumn{3}{c|}{ Panel B: Employees } \\
\hline Foundation ownership & 0.003 & 0.004 & 0.004 \\
& $(0.003)$ & $(0.003)$ & $(0.004)$ \\
\hline & \multicolumn{3}{c|}{ Panel C: Investment } \\
\hline Foundation ownership & $0.016^{* * *}$ & $-0.028^{* * *}$ & 0.002 \\
& $(0.004)$ & $(0.005)$ & $(0.006)$ \\
\hline
\end{tabular}

Abbreviated results. The dependent variable is adapted versions of the sub-indices of the long-termism index in Kappes and Schmid (2013). In Model 1, all observations in our data set are included. In Model 2, the sample is size-restricted to firms with at least 100 employees. In model 3, there are no size restrictions but the control group now consists of family firms. Foundation ownership is a dummy variable equal to 1 if the largest owner is an industrial foundation and 0 otherwise. The following control variables are included but not reported: Ln(total assets); Ln(number of employees); Performance, the ratio of earnings before interest and taxes over total assets; Negative earnings, a dummy variable equal to 1 if EBIT is negative and 0 otherwise; (Foundation ownership*negative earnings), an interaction variable between the dummy for foundation ownership and the dummy for negative earnings; Industry and Year dummies. All models are estimated as pooled OLS models with standard errors clustered at the firm level and corrected for heteroscedasticity. Robust standard errors are reported in the parentheses. $* * * \mathrm{p}<0.01, * * \mathrm{p}<0.05, * \mathrm{p}<0.1$. 


\section{about ECGI}

The European Corporate Governance Institute has been established to improve corporate governance through fostering independent scientific research and related activities.

The ECGI will produce and disseminate high quality research while remaining close to the concerns and interests of corporate, financial and public policy makers. It will draw on the expertise of scholars from numerous countries and bring together a critical mass of expertise and interest to bear on this important subject.

The views expressed in this working paper are those of the authors, not those of the ECGI or its members. 


\section{ECGI Working Paper Series in Finance}

\section{Editorial Board}

Editor

Consulting Editors

Editorial Assistants
Ernst Maug, Professor of Corporate Finance, Mannheim Business School, University of Mannheim

Franklin Allen, Nippon Life Professor of Finance, Professor of Economics, The Wharton School of the University of Pennsylvania

Julian Franks, Professor of Finance, London Business School

Marco Pagano, Professor of Economics, Facoltà di Economia Università di Napoli Federico II

Xavier Vives, Professor of Economics and Financial Management, IESE Business School, University of Navarra

Luigi Zingales, Robert C. McCormack Professor of Entrepreneurship and Finance, University of Chicago, Booth School of Business

Tamas Barko, University of Mannheim

Sven Vahlpahl, University of Mannheim

Vanessa Wang, University of Mannheim 


\section{Electronic Access to the Working Paper Series}

The full set of ECGI working papers can be accessed through the Institute's Web-site (www.ecgi.org/wp) or SSRN:

Finance Paper Series http://www.ssrn.com/link/ECGI-Fin.html

Law Paper Series http://www.ssrn.com/link/ECGI-Law.html 